\title{
La aventura postmoderna
}

\section{1.- La postmodernidad ha venido, nadie sabe cómo ha sido.}

La postmodernidad es otra historia, otra política, otra moral, otra metafísica, otra religión y, por tanto, otra vida. La postmodernidad es el fin de la historia, el final de la historia como confrontación de fuerzas brutales (por sus brutos los conoceréis dice irónicamente W. Borroughs) y del protagonismo guerrero de las grandes potencias. Se trata de la bancarrota de las políticas de los redentores, los grandes poderes que vienen siempre a redimirnos pero, por desgracia, siempre nos explotan. Es hoy también el tiempo de otros modos, de una ética propositiva y no impositiva, que era solamente la correa de transmisión oculta del poder y la dominación establecida. Es el momento también de una nueva metafísica, el final de la metafísica de la fuerza que teoriza hasta los orígenes lo que ocurría en la explotación diaria de las fábricas, de los campos de concentración y de la guerra. ¡Qué hermoso es estirar la pata! decía un rey a sus soldados en el frente de batalla, desde su palacio real. Estamos ante la posibilidad del fin de la violencia, de la violencia de la verdad también, y por eso de la huida de la religión de la brutalidad y los dogmas apabullantes ante los que el pobre creyente solamente debía sucumbir para no verse arrojado a las tinieblas exteriores o al fondo de los infiernos.

El hombre postmoderno aspira a otra vida, a una vivencia menos sistematizada y urgida, menos standarizada y urgente. La postmodernidad es el fin de la era industrial compulsiva, de la democracia siempre vigilada, de la educación de la letra con sangre entra. Pero la postmodernidad no es el fin de los tiempos, sino un nuevo futuro para el hombre en el que los ideales de la modernidad no serán obligatoriamente perseguidos por la violencia. En este sentido, tal vez haya sido G. Vattimo el que se ha situado con más serenidad y clarividencia en las fuentes del problema postmoderno que podría resumirse así: Por lo menos, en cuanto al método, la modernidad ha terminado, si bien sus fines y valores parecen más o menos discutibles y aún darán 
mucho que hablar. Y esto es así, porque el método moderno ha sido la violencia y la imposición, el método de la burguesía. Lo decía Nietzsche muy bien en La Genealogía de la Moral, II, 9, según nos cuenta el mismo G. Vattimo en El sujeto y la máscara: "Todo nuestro ser moderno, en tanto no es debilidad, sino poder y consciencia de poder, se presenta hoy como pura hybris e impiedad (...) Hybris es hoy toda nuestra actitud con respecto a la naturaleza, nuestra violentación de la misma con ayuda de las máquina y de la tan irreflexiva inventiva de los técnicos ingenieros; hybris es hoy nuestra actitud con respecto a Dios, quiero decir, con respecto a cualquier presunta tela de araña de la finalidad y la eticidad situadas por detrás del gran tejidored de la causalidad (...); hybris es nuestra actitud con respecto a nosotros pues con nosotros hacemos experimentos que no nos permitiríamos con ningún animal y, satisfechos y curiosos, nos rajamos el alma en carne viva". ${ }^{1}$

La ética de la fuerza y la metafísica de la fuerza han terminado porque ya sabemos que su realidad más profunda es la brutalidad, si bien, por mucho tiempo, habían creado una noética que traducía una no-ética que les permitía camuflarse de buen sentido, moralidad y pensamiento.

Nos guste o no nos guste, nos encontramos en plena pleamar postmoderna. Con sus flujos y reflujos estamos metidos en la marea, a veces creyendo que no existe, en ocasiones con la idea de que ya pasó, otros dirán que fue una pesadilla para que así no vuelva nunca. Pero no hace falta ser muy sagaces para recordar que esto mismo sucedió cuando sobrevino el existencialismo. No digamos lo que ocurrió con la Nueva Filosofía de los años 70 que muchos se negaron a reconocer, de modo que, aún hoy día, por ejemplo en castellano, es casi imposible encontrar traducciones suficientes de los nuevos filósofos más allá de algunos títulos más llamativos. La crítica a derecha y a izquierda realizadas por H. Levy, Glucksmann, M. Clavel o Benoist no fue recibida en nuestro mundo de ninguna manera o se hizo con una rabieta infantil increíble en una sociedad medianamente culta. Mucho mayor ha sido aún el desprecio a la filosofía postmoderna. Si de la nueva filosofía se dijo que ni era nueva ni era filosofía, al pensamiento postmoderno se le ha querido dar la callada por respuesta o la simple y tradicional sonrisa filosófica que diría Foucault.

Pero los más avispados nunca faltan a la cita. Carlos Díaz, hombre de reconocido ingenio y capaz de cantarle las verdades al lucero del alba, en la primera mitad de los años ochenta conseguía sacar de su paraíso celestial e

1. VAtтimo, G., El sujeto y la máscara. Península, Barcelona 1989, 306. Cfr. NATAL, D., Ante la ética de la fuerza o el tema de nuestro tiempo. Estudio Agustiniano, 15 (1980) 199 223. 
irritar profundamente al discreto encanto de la progresía en varias ocasiones ${ }^{2}$. Así despertó a algunos de los más acomodados radicales de sus sueños dogmáticos y círculos viciosos donde entre las grandes emociones, el buen pasar y el abundante progresismo comenzaban a encarnarse las más reverendas e irreverentes vaguedades.

Jacobo Muñoz, lector infatigable y uno de los pesos pesados entre nuestros profesores de filosofía contemporánea levantaba acta de la situación en un artículo que ponía las cosas en su sitio. En primer lugar recordaba que Federico Onís, entre nosotros, ya había utilizado la palabra postmodernismo al hablar de la caducidad del modernismo literario (1896-1905) por obra del postmodernismo (1905-1914) y el ultramodernismo (1914-1932)3. Del mismo modo subrayaba J. Muñoz que hay un uso obsesivo de la palabra postmodernidad desde los trabajos de S. Sontag, Fiedler, Ihab Hassan, Lyotard y Habermas, que se relaciona con el arte de M. Duchamp, John Cage, B. Perelman, y con la teoría de la historia como post-historia, de la sociedad industrial, según la entendió Toynbee y otros que podría verse como " $\mathrm{El}$ advenimiento de una nueva era, del fin del ciclo histórico cuyo origen habría que situar en el Renacimiento; de la muerte, en suma, o de la radicalización máxima, según otros, de un proyecto histórico, el de la Ilustración europea y de un tipo de racionalidad operante durante siglos de intensa construcción civilizatoria ..." 4 Se trataría del fin de la fundamentación y de la totalización segura e inatacable, con nuevas situaciones de duda, pluralismo, indeterminación, y por tanto de "apertura, eclecticismo, marginalidad, revuelta, deformación, difracción, descreación, desintegración, deconstrucción, desplazamiento, discontinuidad, dispersión, fragmentación, incredulidad, particularismo, diseminación, ruptura, dadaísmo epistemológico, otredad, caos, rizoma"s. En fin, por denominaciones que no quede; es lo que viene ocurriendo en los últimos años y que supone: crisis del sujeto, disolución de la semiótica energética, despèdida de los grandes relatos, renuncia a la armonía total, a la utopía, a la reconciliación total, así como crítica de la razón totalizante e incompatibilidad de paradigmas. Es la crítica de la razón instrumental que se ha incapacitado ya para el conocimiento ético-moral y religio-

2. Cfr. Draz, C., Escucha postmoderno. Paulinas, Madrid 1985. En dos ocasiones tuve la suerte de presentar a Carlos Díaz como conferenciante de la Postmodernidad, en Burgos (La Vid) y en Valladolid (Estudio Agustiniano); en ambas ocasiones hubo un intenso debate con los jóvenes y el nuevo mester de progresía.

3. MUÑOZ, J., Inventario provisional (modernos, postmodernos, antimodernos). Revista de Occidente 66 (1986) 5.

4. Ib., 6

5. Ib., 7 
so, según decía Horkheimer, porque se trata de una Ilustración que lleva consigo "el inclemente dominio sobre una naturaleza externa objetiva y una naturaleza interna reprimida" 6 . Todo lo cual lleva consigo una crisis de la ciencia, a una episteme inestable, y a un cuestionamiento del gran relato de la emancipación 7 . Finalmente, nuestro autor valora la situación de esta manera: “¿Reencuentro final de la modernidad con su propia positividad más allá de toda contestación global? Tal vez. Como es posible también que se trate de un simple signo más de que la modernización civilizatoria que hace siglos nos conforma no ha hecho, a despecho de las apariencias, otra cosa que empezar"'.

José Vega, gran amante del silencio y centinela del misterio, define la situación hodierna de esta manera clarividente: "En todas partes, desde hace ya varios lustros, las campanas están tocando a muerto, aunque, como es natural, los sordos no las oyen. Otros aunque las oyen, se esfuerzan en reanimar el cadáver, esperando ponerlo en pie y que ande de nuevo. Pero reanimar cadáveres son "trabajos de amor perdidos"”. Por tanto es inútil hacerse los sordos y más inútil todavía tratar de reanimar cadáveres de antaño. Estamos donde estamos y tendremos que entendernos o desentendernos, irresponsablemente, del momento actual que es el que nos ha tocado en suerte, nos guste más o menos que eso no depende de nosotros gran cosa. Cualquier otra actitud nos llevaría a caer en lo que señalaba Ortega y Gasset cuando refiriéndose a la realidad española decía que estamos ante un muerto y algunos pretenden enseñarlo a bailar.

Como Peter Sloterdijk, ha sintetizado muy bien todo el problema en su Crítica de la razón cínica ${ }^{10}$ nosotros vamos a describir solamente algunos momentos más decisivos e incisivos de la aventura postmoderna.

El escrito de Lyotard, La condición postmoderna ${ }^{11}$ al final de los años 70 marca el momento en que se pone el nombre, y para algunos mote, a la nueva situación que describe y decide el nuevo pensamiento. Allí se comienza a dar cuenta de la erosión de las grandes ideologías y utopías y de la caída de los mundos ideales. Es el tema del fin de los grandes relatos y metarrelatos: "Simplificando al máximo, se tiene por postmoderna la incredulidad con respecto a los metarrelatos. Esta es, sin duda, un efecto del progreso de las

6. Ib., 15 •

7. Ib., 18 y 19.

8. Ib., 22 .

9. VEGA, J., A propósito de 'Las edades del hombre'. Religión y cultura 35 (1989) 189.

10. SLoterdiJK, P., Crítica de la razón cínica. I y II. Taurus, Madrid 1989.

11. LyotARD, J.-F., La condición postmoderna. Cátedra, Madrid 1984. 
ciencias; pero ese progreso, a su vez, la presupone"12. Es la descomposición de los grandes sistemas de las grandes doctrinas en la que sólo resta el sí mismo y la dogmática individualista que sustituirá poco a poco al dogmatismo oficial. Al mismo tiempo la realidad pragmático positivista vislumbra su bancarrota. No sólo se plantea la cuestión de la cientificidad de la ciencia en sí, se plantea también el problema de su legitimación. Es decir, frente al pragmatista que siempre pregunta: y ¿para qué sirve o para qué vale tal o cual cosa? se presenta el problema de para qué vale lo que se dice que vale. Como lo dice Lyotard: "Y esta pregunta en sí misma, al desarrollarse, conduce a la pregunta, es decir, a la metapregunta de la legitimación: ¿De qué sirve tu "de qué sirve"?"13. Solía decir Ortega que en el mundo actual tenemos ya un automóvil que nos puede llevar rápidamente a Socuéllanos, pero resulta que yo no tengo nada que hacer ni a qué ir allí. Y no obstante, nos hemos acostumbrado a ir a toda prisa sin saber a dónde vamos. Esto hace que hayamos pasado de una ética en que el fin justifica los medios a otra en que los medios se convierten en fines, puesto que ya no hay fines ulteriores.

Al menos parecería que la emancipación, como la suele defender Habermas, sería un fin indiscutible para todos, que se consigue libremente a través del consenso. Pero precisamente vemos que el sistema manipula el consenso en su beneficio o lo convierte en un mero instrumento del poder, no en un resultado del diálogo y las voluntades libres. "Es en esta forma como se encuentra elaborado por Habermas. Pero esta concepción reposa sobre la validez del relato de la emancipación. O bien es manipulado por el sistema como uno de sus componentes en vista a mantener y mejorar su situación. Es objeto de procedimientos administrativos, en el sentido de Luhmann. No vale entonces más que como medio para el verdadero fin, el que legitima el sistema, el poder"14. Así, tanto el buen funcionamiento del sistema como la eficacia y la seguridad se convierten en meros instrumentos del poder, no de la emancipación, como vemos hoy tantas veces en el concepto de "seguridad nacional" y su apelación como pretexto.

Puestas así las cosas, Lyotard introduce la teoría del "disenso" y la inestabilidad como un elemento fundamental de la postmodernidad. El derecho al desacuerdo debe conjurar la tiranía de los "decididores" que imponen su "normalidad-moralidad", su "solidez" y, en definitiva", su orden vital brutal. Así crean el terrorismo de uno y otro signo: "El orgullo de los "decididores", del cual en principio no existe equivalente en las ciencias, vuelve a ejercer
12. Ib., 10
13. Ib., 100.
14. Ib., 109-110 
este terror. Dice: adapte sus aspiraciones a nuestros fines, si no ..."15. Para el postmoderno el derecho a la diferencia es fundamental frente al cinismo de la eficacia. La diversidad de las normas y el derecho al desacuerdo pone en tela de juicio la teoría de la emancipación de Habermas ${ }^{16}$. En este sentido la postmodernidad renuncia al terror, a la ética de la fuerza y de la eficacia, así como a "la lógica de la seguridad que produce la automatización de la sociedad"17. Con estas perspectivas la era postmoderna nos da derecho a una nueva tierra aún desconocida y en cierto modo inagotable: "Se apunta una política en la cual serán igualmente respetados el deseo de justicia y el de lo desconocido"18. No se trata ya solamente de lo que funciona mejor o de lo que gasta menos, queda todavía un margen para lo inconmensurable. No es solo cuestión de poder: "El saber postmoderno no es solamente el instrumento de los poderes. Hace más útil nuestra sensibilidad ante las diferencias, y fortalece nuestra capacidad de soportar lo inconmensurable"19.

Frente a la seguridad y la fe inquebrantable en el método moderno, la postmodernidad tiene que investigar constantemente sobre sistemas y situaciones inestables. Aquí tenemos una de las claves de la postmodernidad, el situarse ante nuestro mundo inestable con normalidad. El objeto de toda ciencia actual es la inestabilidad. "El sistema es llamado inestable: las variables de control varían continuamente, las del estado discontinuamente"20. Así surgen las nuevas teorías caolistas (el mundo como caos) frente a las antiguas teorías del mundo como orden (cosmos). De paso se rompe con un concepto de providencia amaestrada por los poderes dominantes que pica cuando ellos quieren. Einstein se rebelaba contra la idea de un Dios que juega a los dados. Pero Pauli, como gran creyente y científico, se reía de él, pues una providencia domesticada es el gran escándalo de la injusticia y violencia dominante; en cambio la teoría estadística de la materia permite establecer regularidades suficientes para la ciencia, pero rompe la idea de un Dios (y una naturaleza) como supremo "Determinante"21 que al convalidar la injusticia del desorden establecido se vuelve a sí mismo increíble por injusto y cruel motor inmóvil que no tiene corazón, al que se transfiere "religiosamente" la injusticia y la crueldad (humana) inhumana de la sociedad reinante.

15. Ib., 114
16. Ib., 117
17. Ib., 118 , nota 231
18. Ib., 119
19. Ib., 11
20. Ib., 106
21. Ib., 104 . Cfr. ATKINS, P.W., La creación. Labor-Omega, Barcelona 1983. Este cientí-
expone una teoría caolista del mundo. Ver también: BEGLEY, S., Finding Order in Disorder. The science of chaos reveal nature secrets. News Week, december, 21 (1987) 46-47. 
En este sentido, la postmodernidad reclama, con la modernidad, claridad e independencia. Como lo dice F. Féher: "Weber concibió la progresiva separación de las esferas (religiosa, legal, política, económica) como la differentia specifica de la modernidad" 22 . La modernidad y la actualidad, el estar al día, suponía, sin más, la hegemonía de la política y del compromiso social. Pero también aquí las cosas han cambiado: "Sin embargo, parece que, también aquí, el "postmodernismo" ha cerrado un capítulo con su mentalidad ecléctica del "todo sirve". La propaganda política directa coexiste en la ocurrencia de la era postmodernista con la más sutil metafísica ${ }^{23}$. En la misma línea la estética postmodernista rechaza toda servidumbre y sometimiento instrumental de la vivencia a otras esferas: " $\mathrm{El}$ sentimiento postmodernista de "estar de vuelta" obedece a algo más que a una moda pasajera. Los tradicionalistas modernos creían tener una misión que desbordaba la estética sensu stricto. Los postmodernistas rechazan con aire altivo toda identificación con cualquiera de estas misiones, con cualquier exigencia o influencia que provenga de esferas "extrañas"'24. Aquí también se revisan las tradiciones; Europa ya no es todo ni tiene en sus manos el futuro, pero eso no debe hacernos olvidar la misión esencial de la estética de dar sentido a la vida de algún modo. El postmoderno no debe ahogarse en su propio pozo, tiene que beber de él.

Entonces, modernidad y postmodernidad no deben excluirse totalmente. como lo ha aceptado, finalmente Lyotard: "Por el contrario, la actitud postmoderna está siempre implicada en la moderna, en la medida en que la modernidad presupone la compulsión a salir de sí misma y resolverse en algo distinto resultante de un equilibrio final, ya sea ello un orden utópico o la finalidad política que encierran las Grandes Narraciones; de modo que, en este sentido, la postmodernidad es una promesa de la que está preñada la modernidad definitiva y perpetuamente" 25 . Es necesario, por lo tanto, superar los defectos de la modernidad.

Lyotard empleó la palabra postmoderno para dar vida a la contienda sobre el tema, pero no todo en la postmodernidad es pura novedad: "La postmodernidad no es una época nueva, es la re-escritura de ciertas características que la modernidad había querido o pretendido alcanzar, particularmente al fundar su legitimación en la finalidad de la general emancipación de la humanidad. Pero tal re-escritura, como ya se dijo, llevaba mucho tiem-

22. FeHER, F., Comentarios sobre el intermezzo postmodernista. Revista de Occidente, 66 (1986) 58.

23. Ib., 61

24. Ib., 70

25. LyOtARD, J.-F., Reescribir la modernidad. Revista de Occidente 66 (1986) 24 
po activa en le modernidad misma"26. Hoy ya es posible admitir de nuevo que la postmodernidad está en la modernidad por sus ideales mejores, pero no con sus métodos violentos propios del sistema de dominación burguesa. Esta es una conclusión que ha exigido un largísimo y duro debate, con mutuas acusaciones y no pequeños problemas, particularmente entre la teoría de la emancipación de Habermas y la teoría postmoderna del propio Lyotard. En La postmodernidad (explicada a los niños) Lyotard afronta claramente la discusión del problema: "He leido a un pensador que goza de reputación asumiendo la defensa de la modernidad contra aquellos que él llama neoconservadores. Bajo el estandarte del postmodernismo, lo que quieren -piensa- es desembarazarse del proyecto moderno que ha quedado inconcluso, el proyecto de las Luces. Incluso los últimos partidarios de la Aufklärung, como Popper o Adorno, sólo pudieron, si hemos de creer en ellos, defender el proyecto en ciertas esferas particulares de la vida: la política, para el autor de The Open Society; el arte, para el autor de Aesthetische Theorie. Jürgen Habermas (lo habías reconocido ya) piensa que si la modernidad ha fracasado, ha sido porque ha dejado que la totalidad de la vida se fragmente en especialidades independientes abandonadas a la estrecha competencia de expertos, mientras que el individuo concreto vive el sentido "desublimado" y la "forma desestructurada" no como una liberación, sino en el modo de ese inmenso tedio acerca del cual, hace más de un siglo, escribía Beaudelaire"27.

Para Lyotard, el ideal de la emancipación de Habermas no es una realidad inmaculada e inatacable, como no lo es tampoco el ideal de progreso sin más, o el ideal de la ciencia sin más. Como lo dice el mismo Lyotard: "El pensamiento y la acción de los siglos XIX y XX están dominados por la Idea de la emancipación de la humanidad. Esta idea es elaborada a finales del siglo XVIII en la filosofía de las libertades y en la Revolución Francesa. El progreso de las ciencias, de las artes y las libertades políticas librará a toda la humanidad de la ignorancia, de la pobreza, de la incultura, del despotismo y no sólo producirá hombres felices sino que, en especial, gracias a la Escuela, generará ciudadanos ilustrados, dueños de su propio destino"28. De tales ideas surgieron grandes desastres, guerras, explotación, tercer mundo, desempleo y pobreza cultural. Por eso hemos llegado a donde estamos: "Estos ideales están en declinación en la opinión general de los paises llama-

26. Ib., 32

27. Lyotard, J.-F., La postmodernidad (explicada a los niños). Trad. E. Lynch. Gedisa, Barcelona 1987, 12

28. Ib., 97 
dos desarrollados. La clase política continúa discurriendo de acuerdo con la retórica de la emancipación. Pero no consigue cicatrizar las heridas inflingidas al ideal "moderno" durante casi dos siglos de historia"29. Así que también sobre la emancipación hay mucho que hablar, no basta decir "libertad" para ser libres, ni es suficiente pronunciar la palabra "liberación" para liberarse. El sentido de las metanarrativas o relatos-discursos de legitimidad queda en suspenso. Como afirma muy bien Rorty: "Desde el punto de vista de Lyotard, Habermas está ofreciendo una metanarrativa más, una "narrativa de emancipación" más general y abstracta que las metanarrativas freudiana y marxista" 30 . La emancipación discurre también entre paradojas, catástrofes y realidades fragmentadas, y en definitiva, como revolución permanente que debe realizarse desde la vida cotidiana y concreta pero que rompe con un realismo miope. Porque ¿cómo podríamos ser realistas, sin más, cuando no sabemos dónde está la realidad que ha quebrado profundamente y es hoy puro abismo y falla?.

\section{2.- La bancarrota de la realidad.}

Siempre se nos había dicho y sensatamente advertido que debemos ser realistas, eso estaba muy bien y era algo muy seguro. Pero ahora, ¿dónde está la realidad? Al final de La inmortalidad, Milan Kundera afirma taxativamente: "La realidad ya no significa nada para nadie. Para nadie" 31 . En la parte centrąl de su obra, nuestro autor explica, a su manera, esa dura aseveración: "Todas las ideologías fueron derrotadas: sus dogmas fueron finalmente desenmascarados como simples ilusiones y la gente dejó de tomarlos en serio. Los comunistas, por ejemplo, creían que durante el desarrollo del capitalismo, el proletariado iba a empobrecerse cada vez más, y cuando un buen día se demostró que en toda Europa los obreros iban a su trabajo en coche, tuvieron ganas de gritar que la realidad estaba haciendo trampas. La realidad era más fuerte que la ideología. Y precisamente, en este sentido, la imagología la superó: la imagología es más fuerte que la realidad, que por lo demás hace ya mucho que no es lo que era para mi abuela, que vivía en un pueblo de Moravia y lo conocía aún todo por su propia experiencia: cómo se hornea el pan, cómo se construye una casa, cómo se mata un cerdo y se

29. Ib., 97

30. Rorty, R., Habermas y Lyotard sobre la postmodernidad. Revista de Occidente 85 (1988) 72

31. Kundera, M, La inmortalidad. Trad. castellana de Tusquets eds., Barcelona 1990, 410 
hacen con él embutidos, qué se pone en los edredones, qué piensan del mundo el señor cura y el señor maestro; todos los días se encontraba con todo el pueblo y sabía cuántos asesinatos se habían cometido en los alrededores en los diez últimos años; tenía, por así decirlo, un control personal sobre la realidad, de modo que nadie podría contarle que el campo moravo prosperaba cuando en casa no había que comer"32.

Para Peter Sloterdijk: "El concepto realidad es el concepto que más falsamente se utiliza"33. La paranoia de bloques armados se confunde con la realidad; nos encontramos ante un cinismo militar que se une al cinismo comercial, político, económico y religioso: "El modo y manera cómo dos o más magnitudes de poder se vuelven locas mutuamente, en una interacción imaginaria, suministra al hombre de nuestra época su modelo de realidad. Quien se adapta a la sociedad de hoy, tal y como ésta es, en última instancia se adaptará a este realismo paranoico"34. Así, el realismo actual no es otra cosa que la fuerza misma del sistema, la camisa de fuerza que el interés brutal y el poder violento impone a la sociedad normal. Así es como el socialismo se identificaba con la realidad bajo el nombre de "socialismo real"; y, del mismo modo, el nazismo reclamaba de una masa de acero y cemento, la realidad dura y todopoderosa, el bunker de su propia realidad. "También aquí la quinta esencia del endurecerse heroico es decir, ahí, "orgullo", un yo-bloque que se constituye en una máquina en sí misma heroicamente racional. Los manuales de enseñanza del nacional socialismo sabían apreciarlo"35. En esta dinámica, la metafísica de la fuerza se impone y se identifica la violencia y el ser; así el ser es el señor y es lo que se impone sin más: la razón de la fuerza.

El realismo se identifica, de este modo, con el gran estafador, con la mentira general que ya nadie, hoy día, puede creerse de modo que el hombre actual anda a la búsqueda desesperada de la realidad misma y de su resurrección: "Lo que ahora se busca es la desesperada resurrección de lo real: GENTE REAL, VALORES REALES, SEXo REAL. Pero, como diría Baudrillard, si hoy estamos tan desesperadamente fascinados por lo Real, es porque vivimos con el horrible conocimiento de que lo real ya no existe, o más exactamente, que hoy día lo Real sólo se nos aparece como una amplia y seductora simulación" 36 . Tal es el resultado del cinismo del capital, de su nihilismo, así

32. Ib., 141 .

33. SLOTERDIJK, P., Crítica de la razón cínica. II, 24.

34. Ib., II,23

35. Ib., 293

36. Kroker, A., El Marx de Baudrillard, en Pico, y otros Modernidad y Postmodernidad. Alianza, Madrid 1988, 314 
como el último destino de todo poder cínico que no se para en medios ni en fines porque el fin justifica los medios o estos son los fines porque ya no hay fines y sólo importa lo inmediato. Así es cómo el capitalismo y el socialismo real desrealizan el mundo, y su realidad impuesta es una cínica burla de la realidad auténtica. Todo eso lo ha visto muy bien Lyotard cuando dice: "Pero el capitalismo tiene por sí sólo tal poder de desrealizar los objetos habituales, los papeles de la vida social y las instituciones, que las representaciones llamadas "realistas" sólo pueden evocar la realidad en el modo de la nostalgia o de la burla, como una ocasión para el sufrimiento más que para la satisfación. El clasicismo parece interdicto en un mundo en que la realidad está tan desestabilizada que no brinda materia para la experiencia, sino para el sondeo y la experimentación"37.

Esta situación,obliga a reexaminar el mundo objetivo y a definir de nuevo el arte en relación a la realidad, de lo contrario podemos caer en el puro conformismo por el engaño de la realidad: "Aquellos que se niegan a reexaminar las reglas del arte, hacen carrera en el conformismo de la masa metiendo en la comunicación, por medio de las "buenas reglas", el deseo endémico de realidad, como objetos y situaciones capaces de satisfacerlas"38. La postmodernidad pretende atacar un realismo cuyo fin primordial es eludir la realidad al confundirla con el partido o el sistema: "El realismo, cuya única definición es que se propone evitar la cuestión de la realidad implicada en la cuestión del arte, se encuentra siempre en una posición situada entre el academicismo y el Kitsch. Cuando el poder se llama Partido, el realismo, con su complemento neoclásico, triunfa sobre la vanguardia experimental difamándola y prohibiéndola. De todos modos, aún es preciso que las "buenas" imágenes, los "buenos" relatos, las buenas formas que el Partido solicita, selecciona y difunde, encuentren un público que las desee como medicación apropiada para la depresión y la angustia que el público experimenta. El reclamo de realidad, es decir, de unidad, simplicidad, comunicabilidad, etc., no tuvo la misma intensidad ni la misma continuidad en el público alemán de entreguerras y en el público ruso de después de la revolución: he aquí una diferencia entre los realismos nazi y estaliniano" 39.

El realismo del qué-más-da, es el realismo del dinero que satisface todas las necesidades en cuanto éstas se reducen al comercio, al poder del comprar y vender lo humano y lo divino. Este mismo es el realismo de la ciencia y de la industria, incluida la industria de las conciencias, en cuanto en todas ellas

37. LyotaRD, J.-F., La postmodernidad, Barcelona 1987, 15

38. Ib., 16

39. Ib., 16-17 
la realidad se reduce al realismo decretado por el consenso de los socios de mercado y nada más. Para Lyotard: "Esta regla no es de corto alcance. Es la impronta dejada sobre la política del experto y sobre la del gerente del capital por una suerte de evasión de la realidad fuera de las seguridades metafísicas, religiosas, políticas, que la mente creía guardar a propósito de sí misma. Esta retirada es indispensable para que nazcan la ciencia y el capitalismo... La modernidad, cualquiera que sea la época de su origen, no se da jamás sin la ruptura de la creencia y sin el descubrimiento de lo poco de realidad que tiene la realidad, descubrimiento asociado a la invención de otras realidades"40. La contaminación entre la ciencia y los intereses egoístas arroja los mismos resultados: "Cuando los científicos reivindican un poder excesivo lo hacen siempre o casi siempre sobre la base del hecho de que sus actividades tienen mayor peso en la realidad. Siempre se valen de una interpretación "realista". El hecho de interpretar la ciencia como un factor de desrealización del mundo puede llegar a ser también un punto de partida para reducir o mantener en sus límites el poder de los científicos" 41 .

La demolición de la "realidad objetiva" creada por el capitalismo avanzado es hoy la condición necesaria para volver a la realidad primigenia original. Esto es fundamental para rehacer la experiencia del siglo XX triturada por la eficacia y el éxito. Esta demolición no supone, de ningún modo, la utilización de la violencia burguesa de nuevo. Simplemente: "En este momento, la interpretación de la sociedad capitalista avanzada bajo el signo del nihilismo es la condición básica para la emancipación del hombre y para la recuperación del sentido trágico de la teoría critica"42. Esto mismo es lo que se hizo a la caída del imperio romano: una nueva realidad viva, una nueva vida, propiciada por el cristianismo, sustituye al mundo antiguo ya muerto, caduco y corrupto. Esta es la desorientación, en negativo y en positivo, que sigue siempre a la caída de los imperios y el surgir generoso de una nueva realidad que recupera el sentido de la vida, del hombre y de la historia en el nuevo mundo. San Agustín hace referencia a ello al final de sus Confesiones cuando presenta al Dios cristiano como la verdadera fuente de la realidad en la que todo recibe el baño renaciente de la vida. Dice el gran pensador cristiano que a través del Espíritu descubrimos el misterio del hombre, el misterio del mundo y el misterio de Dios que es tanto como encontrar la realidad más profunda porque proviene del que verdaderamente ES: “A través del

40. Ib., 19

41. Vattimo, Filósofo de la secularización. Entrevista de José Ma Herrera y José Lassaga, Revista de Occidente 104 (1990) 131

42. Kroker, A., El Marx de Baudrillard, 316 
Espíritu vemos que es bueno lo que de cualquier modo existe, porque proviene de aquel que existe no de cualquier modo, sino que es el ES"43.

Lo postmoderno nos asegura que ninguna sistematización de la realidad agota la realidad, que no podemos descansar verdaderamente en ninguna formulación ni interpretación definitiva del mundo como algo absoluto, de ahí la prohibición bíblica de hacerse imágenes del Absoluto. Nadie puede igualarse a lo divino, eso sería caer de bruces en la idolatría o en la adoración de sí mismo. Como dice Lyotard: "Por último, es preciso dejar claro que no nos toca de realidad, sino intentar alusiones a lo concebible que no puede ser presentado. Y que no hay que esperar que en esta tarea haya la menor reconciliación entre los "juegos de lenguaje", a los que Kant llamaba "facultades" y que sabía separados por el abismo, de tal modo que sólo la ilusión transcendental (la de Hegel) puede esperar totalizarlos en una realidad real. Pero Kant sabía también que esta ilusión se paga con el precio del terror... Los siglos XIX y XX nos han proporcionado terror hasta el hartazgo. Ya hemos pagado suficientemente la nostalgia del todo y de lo uno, de la reconciliación del concepto y de lo sensible, de la experiencia transparente y comunicable. Bajo la demanda general de relajamiento y apaciguamiento, nos proponemos mascullar el deseo de recomenzar el terror, cumplir la fantasía de apresar la realidad. La respuesta es: guerra al todo, demos testimonio de lo impresentable, activemos los diferendos, salvemos el honor del nombre" 44 . Bien se puede decir que los grandes ideales de la modernidad no han hecho sino comenzar a nacer, pero necesitamos liberarlos de la tentación de la violencia. Por eso la tecnociencia actual es la técnica moderna y a la vez no lo es porque implica una nueva concepción de la naturaleza y del hombre en que la naturaleza antigua y la actual se modifican mutuamente. Por lo demás todo mundo habla de emancipación y liberación. Así, sin violencia, lo hace el relato cristiano de la redención, y también el relato ilustrado de la emancipación del hombre en la libertad por la ciencia; lo mismo hace el relato marxista de la emancipación de la explotación y la alienación que el relato capitalista de la liberación de la pobreza, pero el problema es saber quién decidirá abandonar el sistema de la dominación y el recurso a la violencia de siempre. Esta hoy se encarna fácilmente y se enmascara bajo el nombre de defensa propia o legítima defensa. Se olvida así que esto no es más que el trámite del narcisismo que sustituye a Dios o a los grandes idea-

43. S. Agustin, Confesiones, XIII, 31, 46. La idea de que el genio de san Agustín asume la catástrofe de la caída del Imperio romano y le da un nuevo sentido es del profesor PiNILLOS, J.L., Conversión y hombre interior, Estudio Agustiniano 22 (1987) 416

44. LyotaRd, La postmodernidad, 26 
les por la defensa del sujeto-hombre-pueblo-nación, sea como sea. "Quiero decir: escapar no sólo a la despedida inapelable del sujeto moderno, sino también a su repetición paródica o cínica (la tiranía)" 45 . Este es el momento de acabar con el cinismo de la violencia y con la ética de la fuerza que ha invalidado todo relato de emancipación, tanto en el capitalismo como en el "socialismo real". "Cada uno de los grandes relatos de emancipación del género que sea, al que le haya sido acordada la hegemonía, ha sido, por así decirlo, invalidado de principio en el curso de los últimos cincuenta años. Todo lo real es racional, todo lo racional es real: "Auschwitz" refuta la doctrina especulativa. Cuando menos, este crimen, que es real no es racional. Todo lo proletario es comunista, todo lo comunista es proletario: "Berlín 1953, Budapest 1956, Checoslovaquia 1968, Polonia 1980” (me quedo corto) refutan la doctrina materialista histórica: los trabajadores se rebelan contra el Partido. -Todo lo democrático es por el pueblo y para el pueblo, e inversamente: "las crisis de 1911, 1929" refutan la doctrina del liberalismo económico y la "crisis de 1974-1979" refuta las enmiendas postkeinesianas a esta doctrina moderna" 46 . Con frecuencia el idealismo de la libertad ha llevado al terror y a una realidad impuesta: "Para el ideal de libertad absoluta, ideal vacío, toda realidad, dada, es efectivamente sospechosa de ser un obstáculo para la libertad. No ha sido una realidad querida" 47 . Así la legitimación comunista ha llevado a la burocratización de las personas y a su administración como masa, lo que deslegitima sin más al legislador. En cuanto al capitalismo es la desligitimación ya desde el origen porque no admite otro discurso que el económico en el que todo se compra y se vende incluida la vida humana, la dignidad y la conciencia. Ambos discursos son metafísica del despotismo ${ }^{48}$. Por tanto, en vez de pedir que la libertad se rebaje al nivel de la facticidad, hay que pedir que la realidad práctica se eleve al nivel de la libertad. Es necesario que los poderes fácticos se pongan al servicio de la libertad y no de sus propios intereses. Para ello necesitamos crear una nueva sensibilidad. No basta engañarse con el fantasma del progreso o gritar por la emancipación; hay que ver lo que hay detrás del teatro de la libertad y lo que la realidad normal evidente se calla. La tiranía del basic language es la tiranía principal, la tiranía del despotismo que se ha convertido en realidad y ha sustituido a ésta. Así: "Orwell imagina un despotismo que no tortura (no solamente) la necesidad sino que seduce el deseo. Se puede discurrir acerca de si

45. Ib., 39

46. Ib., 40

47. Ib., 65

48. Ib., 68 
esto sucede aquí o allá. Lo cierto es que en Orwell la última resistencia se experimenta sobre la línea de desfallecimiento, y sobre ella se juega la suerte de una auténtica república" 49 . Esta república es la ciudad la humanidad. Las promesas de desarrollo y emancipación se han difuminado: "Los signos del ideal se han embrollado: Una guerra de liberación no anuncia que la humanidad continúa emancipándose. La apertura de un nuevo mercado no anuncia que la humanidad continúa enriqueciéndose. La escuela no forma nuevos ciudadanos; cuando mucho, forma profesionales. ¿Con qué legitimación contamos para continuar el desarrollo?"50. La realidad se ha petrificado, oxidado, es necesario tratarla. El pensamiento debe ir a fondo a la realidad no puede quedarse en pura estrategia o estratagema. Tal es la misión del pensador como centinela de la realidad y del mundo: "Este curso trabaja la llamada realidad. Desoxida los criterios de la realidad, la pone en suspenso. Si uno de los principales criterios de la realidad y del realismo consiste en ganar tiempo, lo cual me parece que sucede hoy día, entonces el curso filosófico no responde a la realidad actual" 51 . Se pide al pensador que sea estratega y político, pero él no debe serlo. Su misión es ser embajador del respeto y centinela de lo sublime. El primero para que cada cosa sea lo que es en sí antes de toda falsificación, lo segundo para que toda la realidad tenga la posibilidad de serse libremente y no se vea coaccionada por el despotismo y la prepotencia de lo inmediato. Por eso decía Zubiri que la misión del pensador es permitir y dejar que las cosas sean libremente como son en sí, de manera que no sean coaccionadas por la metafísica de la fuerza o del poder y de la circunstancia: Así será posible encontrar el sentido y la realidad de cada cosa antes de que sea arruinada por el cinismo de la fuerza o por el tedio de la vida y la no-ética de que "todo da lo mismo", pues todo es ruido-desinformación-sinsentido y furia-violencia donde la desolación y el desierto acabarían por tomar el lugar de la humanidad. El mundo sería la patria del absurdo del sentido y de la práctica de la frustración. En efecto: "si la historia de la humanidad fuera sólo ruido y furia, habría que admitir pues que la naturaleza, por más que haya dotado a los hombres de esas disposiciones (a la razón) y depositado en ellos esos "gérmenes" de desarrollo de la razón, les negó empero los medios" 52 .
49. Ib., 109
50. Ib., 111
51. Ib., 117
52. Lyotard, J.F., El entusiasmo. Crítica kantiana de la historia. Trad. castellana Gedi- sa, Barcelona 1987,60 
El respeto a la realidad exige no caer rápidamente en una moralina fácil y apresurada que ignora las tensiones de la vida y las dificultades de la historia hasta convertirla en un finalismo ingenuo que se sale de la realidad o trata de atropellarla inconscientemente. Por otra parte, el hombre necesita del entusiasmo, pero no puede caer en un fervor patológico que arrasa la realidad. El entusiasmo debe ser sanado, y por eso lo teme el postmoderno, pues fácilmente degenera en capricho, pero sin él la vida humana no podría adelantar, ni mejorar, ni personal ni comunitariamente. Pero el entusiasmo no debe ser utilizable en función de intereses ni tener otro fin que el de la misma realidad. El entusiasmo es la capacidad para lo mejor en la naturaleza humana, pero esa gran posibilidad debe ser verificada más allá del desierto de la pura indiferencia y de la patología revolucionaria. Nadie tiene derecho a destruir el mundo, pero eso no debe impedir que cada hombre colabore al bien de la humanidad desde sus, pequeñas o grandes, posibilidades y cualidades a pesar de las propias limitaciones. En eso el postmoderno es infinitamente universal, católico ecuménico, e infinitamente concreto y personalista. Pero eso no permite creer que "todo vale" o que todo "es igual" pues los ideales pueden ser enormemente sublimes pero su realización bochornosa. Entre una y otra cosa, media un abismo como sabemos por la historia: "Auschwitz, un abismo abierto cuando hay que presentar un objeto capaz de validar la proposición de la idea de los derechos del hombre; Budapest 1956, un abismo abierto frente a la proposición de la idea del derecho de los pueblos; Kolyma, un abismo abierto frente a la proposición del concepto especulativo (ilusorio) de la dictadura del proletariado; 1968, un abismo abierto frente a la ilusión "democrática" que ocultaba la heterogeneidad del poder y de la soberanía"53. 'Y como éstas hacéis muchas' diría el Dios de los cristianos. "Pero la pretensión de la proposición del capital a validar todas las proposiciones según su propio criterio y la impostura que coloca al capital en el lugar del juez crítico, son materias que (en el sentimiento no nombrado del que sugería que se llamara La Begebenheit de nuestro tiempo) permiten juzgarlas, hacer su crítica y restablecer en sus derechos al tribunal crítico que sin embargo no será lo mismo que el tribunal criticista"54. Los intereses del capital no pueden ser los criterios últimos ni definitivos de la realidad por mucho que entusiasmen a F. Fukuyama. No podemos caer en una teleología ingenua de la realidad y menos cuando se quieren ignorar los sufrimientos de millones de seres humanos. Eso, además de una gran superficialidad

53. Ib., 124

54. Ib., 130 
hedonista, sería una enorme crueldad. Y la razón humana y sus ideales no puede ser cruel, pues ya no sería razón, ni humana. Hoy más que nunca es necesario respetar lo inmediato sin arrollar lo transcendental, de otro modo no habría ni realidad, ni libertad, ni historia humana. Y esto es fundamental para el pensador actual y para el hombre postmoderno: "Tal vez la responsabilidad reflexiva sea hoy también discernir, respetar y hacer respetar los diferentes pareceres, establecer la inconmensurabilidad de las exigencias transcendentales propias de las familias de proposiciones heterogéneas y encontrar otros lenguajes para expresar lo que no se puede expresar en los lenguajes que hoy existen. Eso será ser fieles, sin paradoja, a la idea kantiana de la "cultura" entendida como rastro de la libertad en la realidad; dice Kant (KUK, 24) que la cultura es "la aptitud de proponerse en general fines" 55. Pero hoy al actuar como incultos y bárbaros utilizamos todo y a todos como medios y ya no hay fines ni ética. Y por eso (los problemas no son tan nuevos como parece a veces) Kant continua diciendo: "Hoy, cuando se probaron (eso es lo que se cree) en vano todos los caminos, reinan el hastío (Ueberdruss, la saciedad, el hastío el taedium) y un indiferentismo completo" 56 .

Al fin padecemos la enfermedad de la realidad, de la vida y de la historia. Entonces todo se vuelve gris y aplanado. Michel Ende lo ha descrito así: "¿Qué enfermedad es ésa? -Al principio apenas se nota. Un día, ya no se tiene ganas de hacer nada. Nada le interesa a uno, se aburre. Y esa desgana no desaparece, sino que aumenta lentamente. Se hace peor de día en día, de semana en semana. Uno se siente cada vez más descontento, más vacío, más insatisfecho con uno mismo y con el mundo. Después desaparece incluso este sentimiento y ya no se siente nada. Uno se vuelve totalmente indiferente y gris, todo el mundo parece extraño y ya no importa nada. Ya no hay ira ni entusiasmo, uno ya no puede alegrarse ni entristecerse, se olvida de reír y llorar. Entonces se ha hecho el frío dentro de uno y ya no se puede querer a nadie. Cuando se ha llegado a este punto, la enfermedad es incurable. Ya no hay retorno. Se corre de un lado a otro con la cara vacía, gris, y se ha vuelto uno igual que los propios hombres grises. Se es uno de ellos. Esta enfermedad se llama aburrimiento mortal"57.

Así hemos perdido también, en la vida, la razón, "todo vale", por eso ya no hay nada que valga la pena, todos los valores se han remitido al valor de

55. Ib., 130

56. Ib., 29 230

57. Ende, M., Momo. Trad. castellana de Salvat-Alfaguara, Madrid-Barcelona 1987, 
comerciar, y la razón de la vida se ha reducido a pura "razón social". Entonces el mundo se ha vuelto violento, porque: “¿La violencia y el sinsentido no son, al fin y al cabo, una y la misma cosa? (Horkheimer)" 58

\section{3.- La agonía de la razón cínica}

La violencia y la insolencia se autovalidan a sí mismas. La misma verdad se utiliza como arma de la mentira y todo lo que llamamos razón no es más que razón social, un medio más de la lucha del hombre contra el hombre, un intento obstinado de hacer pasar por real lo que no es real y de convertir la no-ética en una noética; así es gran parte de la formación actual: "La constitución de la sociedad 'trae consigo algo que se diría el primer paso hacia la adquisición de ese enigmático impulso a la verdad. Pues se puntualiza, entonces, qué debe en adelante ser la verdad', es decir, se inventa una denominación de las cosas válidas y obligatorias para todos, y la legislación del lenguaje dicta también las primeras leyes en materia de verdad; pues se origina entonces, por primera vez, la oposición entre verdad y mentira. El mentiroso usa las denominaciones convencionales, las palabras, para hacer pasar por real lo que no es real... Abusa del rígido esquema convencional trastocando, cuando no invirtiendo a su antojo las denominaciones" (Sobre la verdad y la mentira en sentido extramoral, trad. italiana de E. Logatto, en F. NiETZSCHE, Scriti minori, Napoles, Ricciardi, 1916,1)59.

El hombre actual con frecuencia carece de convicciones y sus ideas de las cosas son meras nebulosas que pasan raudas por su cielo encapotado y triste, obscuro, difícil e indescifrable. Su vida impropia y confusa responde a la razón ajena y se reduce a una realidad exangüe de vida, de ideas y de sentimientos: sombras y fantasmas de sí mismos los hombres de nuestro mundo flotan en la galaxia impersonal de la indiferencia y del desierto vital. Así lo había dicho Nietzsche y lo reconoce G. Vattimo: "La mayoría de los hombres, piensen lo que piensen y digan lo que digan siempre de su "egoísmo", pese a él, en toda su vida, no hacen nada por su ego, sino sólo por el fantasma del ego que se ha formado sobre ellos, en la cabeza de quien los rodea, y que se les ha transmitido; como consecuencia de ello, viven todos en una nebulosa de opiniones impersonales y semipersonales y de juicios de valor arbitrarios, casi poéticos; cada uno de ellos vive siempre en la cabeza de otro

58. HANDKE, P., El momento de la sensación verdadera. Alfaguara, Madrid 1981, 10

59. VAтTimo, G., El sujeto y la máscara, 45 
y tal cabeza a su vez en otras cabezas: jun curioso mundo de fantasmas que sabe darse, en todo esto, un aire tan juicioso-. Esta nebulosa de opiniones y de hábitos se desarrolla y vive casi independientemente de los hombres que envuelve; en ella reside el enorme influjo de los juicios generales sobre el hombre -todos estos hombres desconocidos para sí mismos creen en la exangüe entidad abstracta "hombre", es decir, en una ficción; y cada transformación introducida en esta entidad abstracta a través de los juicios de los individuos poderosos (como príncipes y filósofos) pesan extraordinariamente y en una medida irracional sobre la gran mayoría... (Aurora, 105)"60. El hombre es una realidad, por tanto, creada a imagen y semejanza de la época en que vive y sus intereses. Y este hombre es incapaz, con frecuencia, de oponer su propia razón a la ficción de la razón social que en su mentira se impone. Esta razón social pasa a la educación y a la moral. El individuo es educado para ser función del rebaño y se le atribuye valor sólo en tanto que función; pero el funcionalismo ha dejado de funcionar. Se han derribado ya los edificios de la arquitectura funcionalista porque ya no eran funcionales. Se ha venido abajo el sentido de lo meramente útil, se ha descubierto que la ética de la fuerza ya no tiene futuro. A veces el mismo pensamiento encubre una camisa de fuerza, pero que ya es incapaz de dominar la realidad. La moralina ya no engaña a nadie y ha perdido su poder (Aurora 53). Y estamos en el fin de la religión y la moral de la violencia. Porque "Cuando la vida social presenta un carácter menos violento, las decisiones últimas (sobre las denominadas cuestiones eternas) pierden importancia. Reflexiónese sobre cuán raramente, ya hoy, un hombre se ocupa de ellas". (Humano demasiado Humano, IV, 3, 350). ${ }^{61}$

Es necesario romper con la civilización y con la ética de la coacción y de la venganza. Es menester abandonar la ética como forma y medio de coacción sobre la persona; no es posible seguir con una moral que incluye sutilmente la fuerza y la violencia y declara culpable todo lo que es natural, normal y tranquilo. Mucho ha hecho perder a los hombres la razón, el instinto y el deseo de rivalidad y de venganza. Acaso nada ha llevado más dolor a la humanidad que esta enfermedad subterránea de la humillación de los demás y el deseo de poder. Tanto que, como dice Nietzsche, esa razón ha sido declarada con frecuencia de utilidad social. Y así se ha creado el derecho de encarcelar y de matar. Entonces la violencia triunfa en la vida social como recurso supremo e incide también poco a poco invadiendo la vida espiritual

60. Ib., 96

61. Ib., 106 
y la religión. Así llegamos a la metafísica de la fuerza como razón y esencia del ser que conduce al hombre a la enfermedad de las cadenas; como dijera Nietzsche. Es así como "el hombre se substrae al mundo de la ratio; o mejor, como medio de preparar al ultrahombre a través de su liberación de todas las funcionalidades y las utilizaciones que pretenden imponérsele con la moral del rebaño (que es la moral tout court) y con su predicación de la bondad, de la sumisión, del altruismo y del desinterés"62. Este hombre nuevo, es capaz de determinarse por sí mismo, de una manera saludable, sin dejarse dominar por la masa, vital, sin miedos ni temores, y construir una nueva ratio, ajena a la lógica del sistema, que conecta con los excluidos, los marginados y los explotados. Comienza una nueva humanidad que anticipa realidades que a veces tampoco él mismo se halla en condiciones de realizar del todo ni siquiera de comprender en toda su profundidad63. Surge entonces una nueva libertad y una nueva razón de ser de la que depende el porvenir.

De hecho el pensamiento tradicional encierra una violencia que intenta ocultar bajo apariencias pretendidamente inocentes ${ }^{64}$. Y así, con frecuencia, lo ha de utilizar todo funcionalmente en paz. Pero como nos advierte el Angelus Silesius: "la rosa carece de porqué, florece porque florece". No hay más razón instrumental. Es el momento de la paz y del sosiego y de la muerte del voluntarismo. Así la realidad se vuelve humilde y sencilla, es la huella del misterio que no oprime jamás al hombre, sino que lo transfigura. Es la realidad como alusión y la razón como gozo y libertad. Es el pensamiento débil frente a la razón como estrategia. Por eso, tampoco se trata de volver a un "ensañamiento nihilista" y menos contra los clásicos. Como lo dice muy bien J. Derrida: "Le tengo mucho cariño a todo lo que reconstruyo a mi manera, los textos que me apetece leer desde este punto de vista reconstructivo son textos que me gustan, con ese movimiento de identificación que es indispensable para leer y son textos cuyo porvenir pienso que está lejos de estar agotado. Creo, por ejemplo, que Platon -éste es el destino de las firmas- tiene que ser leído, todo el tiempo, y la firma de Platón no está acabada, al igual que no lo está la de Nietzsche ni la de San Agustín -estoy seguro$y$, de bastantes otros. Por consiguiente (...) me hallo en una relación de recelo amoroso respecto a estos textos, en absoluto en la del ensañamiento nihilista (no se puede leer nada en esta últimas condiciones) (...)" (L'oreille de l'autre. Textes et débats avec Jacques Derrida, Montreal 1982, 119)"65. Se

62. Ib., 325

63. Ib., 332-333

64. De Peretti, Ch., Jacques Derrida. Texto y deconstrucción. Anthropos, Barcelona 1988,23

65. Ib., 172, nota 57 
trata de atender a lo inefable del texto de la realidad, sin caer en una lectura reduccionista de la vida entendida a nuestro antojo, según los propios intereses, porque la realidad y la verdad son esencialmente "alusión sin fondo y sin fin"66, el camino desde el abismo y hacia el "abismo" en el que el misterio del hombre y del mundo mutuamente se interpelan.

Pero esta capacidad de escucha, de respeto y de otear el futuro es la que precisamente la modernidad había perdido, abismada en su tarea funcional e instrumentalista. De ahí la rebelión postmoderna. Como bien lo ha expresado J. Picó: "El ámbito de este debate se enmarca en una conciencia generalizada del agotamiento de la razón, tanto por su inçapacidad para abrir nuevas vías de progreso humano como por su debilidad teórica para otear lo que se aviecina"67. Los modelos que venían determinando nuestra vida le parecen al postmoderno substancialmente defectuosos, plagados de contradicciones y de opresiones burocráticas normalizadas en las que naufraga la razón moderna. Así: "El crecimiento de la razón instrumental no conduce a una realización concreta de la libertad universal, sino a la creación de una "jaula de hierro" de la racionalidad burocrática de la cual nadie puede escapar"68. Entonces el poder crea la realidad en vez de atenerse a ella. Y el hombre y el mundo se convierten en fantasmas que quedan al descubierto: "El fenómeno del hombre moderno ha llegado a ser totalmente apariencia: no se hace visible en lo que representa, sino que más bien se oculta tras esa representación. En la tarea de la reconstrucción de los resultados de la moral, de la metafísica y la religión, se erosiona también ese lugar de posible seguridad que es la interioridad del yo. El "mundo verdadero" acaba convirtiéndose en una fábula"69. En ella se difuminan todas las buenas intenciones de la modernidad ilustrada. Era pues necesario abandonar el discreto encanto de la burguesía para buscar nuevos horizontes. La fe en la modernidad, de hecho, estaba perdida. Ya no se cree en fantasmas, hay que vivir "aquí y ahora" en busca de calidad de vida y de cultura personalizada. Se pierde la fe en la revolución y el progreso que tanto nos ha decepcionado. "La atención por lo social se vuelve hacia el individuo y se difunde el narcisismo individual y corporativo. El individuo sólo tiene ojos para sí mismo o para su grupo. El capitalismo autoritario cede el paso al capitalismo hedonista y permisivo que acaba con la edad de oro del capitalismo competitivo"70. Se busca la realización personal y se abandona la fe en el colectivo. Se deja atrás la dialéctica

66. Ib., 165

67. Pico,J., (compilación) Modernidad y Postmodernidad, 13

68. Ib., 16

69. Ib., 18

70. Ib., 37 
educativa entre ideal y realidad ${ }^{71}$. Quiebra la escuela y los grandes maestros, así como la intelectualidad arrogante. Quiebran los partidos como pompas de jabón. Así estamos ante un nuevo crepúsculo para el que se espera un nuevo día. Ha quedado al descubierto la gran estafa del cinismo estatal y prepotente, el cinismo de la ciencia y la religión, así como el cinismo amoroso, militarista y médico ${ }^{72}$. Pero no todo está perdido, la realidad y las cosas no son malas en sí -eso sería maniqueísmo- pero queda un trabajo hercúleo por hacer, para rescatar la vida de la actual razón cínica y destructiva. El postmoderno no puede desanimarse, él no es el único que ha hecho en la historia esta enorme tarea. Siempre ha habido hombres en todas las esferas, científicos, médicos, militares, religiosos, que han luchado contra la demolición de la vida humana y contra la destrucción; hoy necesitamos recordarlos especialmente cuando la tarea se presenta tan dificultosa y parece que todo se hunde. De modo que, como decían los antiguos, de donde la destrucción toma su origen, de ahí le viene su salvación. Así, la postmodernidad, aparentemente trivial e intranscendente, superficial, hedonista e individualista, en el fondo será comunitaria, solidaria-sensible, si nosotros queremos y lo intentamos.

De hecho la postmodernidad surge cuando las totalizaciones de emancipación se ponen en cuestión, el capitalismo clásico ya no funciona bien. Hay un peligro de neoconservadurismo, como pretende $\mathrm{D}$. Bell, pero también es posible avanzar. Sin embargo la historia no será ya nunca más unilineal. Tampoco para el marxismo como lo han demostrado los últimos tiempos del Este. Los grandes bloques seguros se cuartean, los mesianismos fáciles y rápidos se hunden cada vez más. El revolucionarismo fácil de mayo del 68 se ha venido abajo. El periódico Lucha continua, defensor del radicalismo violento, tuvo que cerrar. Comienza el "pensamiento débil" así llamado porque no admite la ética de la fuerza: tiene más razón quien tiene más poder, más armas y éstas dictan la moral. Como lo ha descrito G. Vattimo: "El pensamiento débil se desarrolló en estos años (de 1975) como un esfuerzo para imaginar una posibilidad de transformación social desde el interior del capitalismo tardo-moderno, de acuerdo con la idea de esos movimientos de liberación internos a la sociedad capitalista que no implican como condición de realización la toma del poder en el sentido clásico leninista"73. Es inútil

71. SLOTERDIJK, P., Crítica de la razón cínica, I, 124 y 128

72. Ib., II, $12-110$

73. VATtimo, filósofo de la secularización (entrevista), Revista de Occidente 104 (1990) 123

74. Ib., 126

75. FrISBY, D., George Simmel: primer sociólogo de la modernidad, en PICO, J., (comp.) Modernidad y Postmodernidad, 68 
tomar posiciones teóricas radicales si no se implica uno en su realización, aquí y ahora, y no se puede aplazar la emancipación indefinidamente con la disculpa de un futuro excelente, pero ilusorio, como ha ocurrido tanto en el marxismo. Así, "El esfuerzo del pensamiento débil es también un esfuerzo por encontrar una posibilidad de emancipación que no esté ligada a las rigideces de la tradición revolucionaria, de la política dialéctica"74. Del mismo modo que es inútil creer que la sociedad marcha excelentemente bien cuando muchos hombres no tienen lo necesario en la sociedad de bienestar ni pueden desarrollar sus cualidades ni vivir una vida digna. El hombre no vive ni come de los indicadores macroeconómicos aunque éstos sean muy importantes. El postmoderno pretende un mesianismo del presente que si no alcanza a todos será puro cinismo, partidista, de ghetto. Es el momento actual, pero el de todos, el que debe ser resuelto y salvado por todos y para todos. Ya no hay más una humanidad de vanguardia y otra de segunda fila: o todos somos iguales y todos somos realmente, o estamos todavía de lleno en el racismo y en la opresión. El individuo, el pequeño grupo, el fragmento tiene un derecho inalienable sin el cual el conjunto o la totalidad nada significan. Por lo demás el individuo alienado necesita de la excentricidad, de la moda permanente, del sobresalto y de la borrachera de sí mismo. Como lo ha dicho muy bien D. Frisby: "Hemos visto ya que la respuesta a la cultura objetiva alienante es, por parte de sus víctimas, una creciente indiferencia hacia la gente y los valores, un hastío creciente hacia el mundo y un retraimiento en la esfera de lo interior"75. A falta de valores y convicciones domina lo inmediato. En otras palabras: "A través de la moda los individuos buscan contrapesar "la superioridad, autonomía e indiferencia del cosmos en el que viven"76. Y a través de la vorágine de la diversión, el individuo realiza un esfuerzo supremo por alcanzar lo absoluto que se ha esfumado, evaporado y eclipsado, con el deseo de un presente futuro inmaculado y estable.

Habermas protesta contra la identificación de la modernidad la pérdida de valores y los extremismos, pero no resiste la tentación de llamar "neoconservadores" a los postmodernos. Hace bien en defenderse contra los que identifican modernidad y terrorismo individual y de Estado ${ }^{77}$, pero no parece ofrecer demasiadas respuestas a los que se cansan de esperar en las promesas de emancipación de la Ilustración burguesa o del socialismo real, con todos sus cinismos.

76. Ib., 79

77. Habermas, J., Modernidad versus postmodernidad, en Pico, J., (comp.) Modernidad y Postmodernidad, 98 


\section{4.- Modernidad y postmodernidad}

La postmodernidad es un nuevo ciclo de la humanidad, en el que se rechazan las tiranías de las totalidades, aunque lo más legítimo de la modernidad quede preservado. Se trata de una nueva episteme frente a la razón moderna: "El momento de la postmodernidad es una especie de explosión de la episteme moderna, explosión en que la razón y su sujeto -como guardián de la "unidad" y del todo- saltan hechos pedazos"78. Habrá que deshacer gran parte de lo hecho aunque haya que rehacerlo de nuevo. Al fin y al cabo también "los hechos" son cosas que nosotros hacemos. Esta conciencia es esencial a la postmodernidad. Por eso se reclama del arte de la desdefinición que unas veces puede terminar en mera alucinación y otras puede llevar a una aurora de la humanidad. En cualquier caso se rechaza siempre la coerción burguesa moderna, íntimamente ligada al sistema, y se busca, por lo menos, una sociedad de convivencia menos rígida y más distendida, menos asfixiante-agobiante y más acogedora. Así es como "Frederic Jameson ve en el rechazo postmodernista de la violencia de una razón "totalizante" la posibilidad de un concepto nuevo, por así decirlo, dialógico, postmoderno, de totalidad. Lo que Jameson tiene en mientes podría caracterizarse con Adorno como una "unidad no violenta de la múltiple"; el propio Jameson habla de una "relación por vía de diferencias"79. Para la izquierda significaría un rechazo de la totalidad social desde arriba y una mayor participación de todos, donde las personas se vean como tales y realicen su vida, además de su función social.

Para Baudrillard la revolución postmodernista ya ha llegado y hay que empezar a vivirla así, no esperando el futuro, puesto que el mesianismo se realiza en el presente actual o es pura quimera. Es la hora de vivir la libertad personalmente, aquí y ahora; es el momento de acercarse a la realidad y sin miedo alguno a los otros y concretamente es como el hoy de la confianza en nuestras posibilidades aquí y ahora. Hay que vivir ya la utopía sin espejismos, pero con todas nuestras posibilidades actuales. Sólo así es posible vivir todos plenamente y realizar los verdaderos ideales esenciales de la modernidad y libertad, igualdad, fraternidad, sin remitirlos continuamente al futuro indefinido. "La postmodernidad sería, por tanto, una modernidad sin lamentos, sin ilusión de una posible "reconciliación entre juegos de lenguaje", sin "nostalgia de totalidad ni de unidad, de reconciliación del concepto y la sen-

78. Wellmer, A., La dialéctica de modernidad y postmodernidad, en PICO, J., Modernidad y postmodernidad, 105

79. Ib., 106 
sibilidad, de experiencia transparente y comunicable", en una palabra, una modernidad que acepta la pérdida del sentido de valores y de realidad con una jovial osadía: el postmodernismo como "gaya ciencia""s0.

Para Lyotard la postmodernidad refleja el "agotamiento" de la razón moderna y así nos lo muestran las complicaciones y las convulsiones de"nuestro tiempo. La postmodernidad no es sólo una vanguardia, un programa o una moda teórica, sino que es, sobre todo "la conciencia difusa de un final, de un tránsito", así nos indica una falla en las creencias modernas y, como consecuencia, nos lleva cerca "del descubrimiento de cuán poco real es la realidad"11. Al mismo tiempo se rompen continuamente, sin casi darnos cuenta, las reglas del juego y eso nos obliga al diálogo creador sin descanso y sin precipitación. El tema de la postmodernidad es la demolición de la razón "totalizante" y por tanto nos incita a la creación personal y solidaria del futuro y de su norma. Eso nos obliga al abandono de la mera razón social y del instinto del poder. Exige caminar, por tanto, más allá de la dominación "interna, externa y social". Esta queda desenmascarada cuando reconocemos que: "En el corazón del pensamiento discursivo se hace visible un elemento de violencia, una subjeción de la realidad, un mecanismo de defensa, un procedimiento de exclusión y dominación, una ordenación de los fenómenos para controlarlos y manipularlos, un impulso hacia un sistema paranoico"82. Ese impulso del pensamiento tiene además su reflejo en la vida práctica, pues "los procesos de racionalización de la modernidad, (esto es, la burocracia; el derecho formal, todas las instituciones formalizadas de la economía moderna y de la sociedad moderna) son también manifestaciones de esta razón objetivante, unificante, controladora y disciplinante"83. Así mismo se quiere encontrar una seguridad y una identidad tan fuerte que casi lleva al delirio. Entonces "la razón se torna finalmente cínica y positivista, un mero aparato de dominación. Este aparato de dominación ha conducido en la sociedad industrial avanzada a un sistema total de delirio, en el que el sujeto, otrora portador de la Ilustración, se ha vuelto superfluo. El individuo se contrae a un complejo de relaciones convencionales y modos de funcionamiento que el sistema exige de él. El animismo había dado vida a las cosas, el industrialismo ha reificado la vida" 84 . El postmoderno sobre todo quiere vivir, ya que con frecuencia tiene la impresión de que está muerto. Se trataría de que la humanidad cobre nueva vida, entre tantas muertes, para salir de la cultura
80. Ib., 110
81. Ib., 114
82. Ib., 119
83. Ib., 119
84. Ib., 120 
actual de la muerte y de la violencia, en la que la razón totalizante presta buena conciencia a la opresión organizada como Estado, mientras la razón radical bendice el terrorismo individual igualmente totalitario. Necesitamos pues de la postmodernidad para superar este círculo infernal del colectivismo y del individualismo, para llegar a una autodeterminación de la persona y de la sociedad donde cada cual pueda vivir y ser él mismo. No se trata de volver atrás ni de despreciar la democracia, ni la persona ni los deseos de justicia ni el verdadero sentido, sino de realizarlos plenamente en la práctica. Este es el intento de la postmodernidad. Mientras tanto: "La dialéctica de modernidad y postmodernidad está todavía por escribir. Pero sobre todo requiere ser puesta en práctica. "Nuestra época", escribe Castoriadis, "exige un cambio de sociedad. Este cambio, sin embargo, no puede obtenerse sin una autotrascendencia de la razón". La postmodernidad, entendida correctamente, sería un proyecto. El postmodernismo, empero, en la medida en que sea algo más que una moda, una expresión de regresión o una nueva ideología, cabe entenderlo como una búsqueda, como una tentativa de registrar las huellas del cambio y de permitir que aparezca con más nitidez el perfil de ese proyecto" 85 .

La postmodernidad se fragua al final de los años 60 . Al comienzo de la década de 1970 se va perdiendo la fe en las promesas radicales. Ante la domesticación del arte y la "industria de las conciencias" (Enzensberger) se declara la bancarrota de la modernidad y se busca autonomía personal y una sociedad alternativa que permita una nueva creación humana y dé lugar a una nueva sensibilidad. La utopía moderna, de hecho, había fracasado: "Las perspectivas de abundancia ilimitada, la estabilidad política y las nuevas fronteras tecnológicas de la era Kennedy se derrumbaron rápidamente y la conflictividad social surgió con fuerza en los movimientos pro-derechos civiles, en los disturbios urbanos y en el movimiento antibélico"86. Las utopías de mayo del 68 quedan abrasadas en la guerra del petróleo de 1973. Así no deja de ser preocupante cierto optimismo excesivo del talante postmoderno sobre todo si tenemos en cuenta lo poco que hemos avanzado. En ese sentido la postmodernidad es algo paradójica. En efecto: "La paradoja de los años 70 es más bien que la búsqueda postmodernista de la tradición y la continuidad cultural, que yace debajo de toda la retórica radical de ruptura, discontinuidad y rupturas epistemológicas, ha regresado a esa tradición que

85. Ib., 138

86. HUYSSEN, A., En busca de la tradición: vanguardia y postmodernismo en los 70, en Pico, J., Modernidad y Postmodernidad, 146 
fundamentalmente y por principio despreciaba y negaba todas las tradiciones"87. Ciertamente los años 70 suponen para todo el continente europeo una profunda crisis cultural y política que le obligan a buscar sus raíces, "a menudo un pasado alternativo" para afrontar el futuro porque lo de siempre ya no sirve. El hombre postmoderno siente en su corazón también la necesidad de un futuro alternativo. "Las prácticas culturales de los 70 -a pesar de la teoría postmodernista- señalan de hecho la necesidad vital de no abandonar la historia y el pasado en manos de los neoconservadores traficantes de la tradición resueltos a restablecer las normas del primitivo capitalismo industrial: disciplina, autoridad, ética del trabajo y familia tradicional"88. En este sentido la postmodernidad es un hacer y un deshacer que intenta algo. sorprendente y nuevo sin llegar siempre a conseguirlo del todo. Se trata de moverse con inteligencia en el callejón sin salida en que se encuentra nuestra historia. A veces la postmodernidad parece "andar hacia atrás para salir de un callejón sin salida donde los vehículos del vanguardismo y el postmodernismo han quedado bloqueados"... "Especialmente frente a los ataques neoconservadores globales a la cultura modernista, vanguardista y postmodernista, continua siendo políticamente importante defender esta tradición en contra de las insinuaciones neoconservadoras que hacen a la cultura modernista y postmodernista responsable de la crisis actual del capitalismo"89. Pero esto no da toda la razón a Habermas que parece ignorar el rechazo de la postmodernidad a toda visión totalizadora del hombre o de la historia que olvide los marginales, y la realidad de la vida. Esto no debe llevarnos a una postmodernidad domesticada e inmaculada.

Una nueva sensibilidad comienza a aparecer. Pero no todo está conseguido. Por eso no hay que elogiar ni ridiculizar la postmodernidad en bloque. "Lo postmoderno debe ser libertado de sus paladines y de sus detractores"90. Pero algo grave se está jugando en esta batalla por la postmodernidad y su control en torno a los años 80 . La fábrica funcional ya no es un buen modelo de vivienda. El postmodernismo rechaza el elitismo modernista contra la cultura de masas. Hay una rebelión contra el modernismo establecido en la que la crítica, la resistencia y el enfrentamiento al sistema fueron definidos en términos no modernistas. Las iras postmodernistas se dirigieron contra el "modernismo-culto" y elitista que parecía ser el único depositario y guardián de la historia, pero que era el legitimador de la "hegemonía" bur-

87. Ib., 152

88. Ib., 156

89. Ib., 158

90. HuYssen, A., Cartografía del postmodernismo, en PICO, J., Modernidad y postmodernidad, 194 
guesa. Así "el postmodernismo en los 60 estuvo caracterizado por una imaginación temporal que mostró un poderoso sentido del futuro y de las nuevas fronteras, de ruptura y discontinuidad, de crisis y conflicto generacional, una imaginación que recuerda a otros movimientos continentales de vanguardia anteriores como el dadaísmo y el surrealismo antes que al modernismo culto. De este modo, el resurgimiento de Marcel Duchamp como padrino del postmodernismo de los años 60 no es ningún accidente histórico"91. Era la continuación del ataque del arte auténtico a las "instituciones sociales hegemónicas" y prepotentes. Así es como: "La postmodernidad abrigó la expectativa de un mundo "post-blanco", "post-machista", "post-humanista" o "postpuritano". Se observa fácilmente que todos los adjetivos de Fiedler apuntan al dogma modernista y a la noción del establishment cultural relativo a la civilización occidental"92. En efecto, es esencial a la postmodernidad la disolución de la cultura europea y la civilización occidental como modelo ejemplar de toda civilización ${ }^{93}$.

Una vez agotado el optimismo triunfal de los años 60 , los años 70 son la dispersión y la diseminación a partir de las ruinas del modernismo. El socialismo real, el elitismo, y el populismo nacionalista han perdido sus apoyos. La cultura africana, oriental, latinoamericana, lo no europeo, el feminismo, las alternativas comienzan a encontrar su propio espacio. La izquierda radical ridiculiza el postmodernismo como neoconservador y se obsesiona con el "realismo" modernista, pero ella tiene los mismos problemas. La reciente disolución del Este viene a confirmar que la postmodernidad es la continuación del mayo del 68 también como marxismo en libertad. El que los intelectuales conservadores rechacen la postmodernidad viene también a confirmanos que hay que tener precaución y no confundirlo todo. De hecho: "Dado el campo de acción estética del término postmodernismo, ningún neoconservador de hoy identificaría el proyecto neoconsevador como postmoderno ni en sueños"94. El neoconservador como Daniel Bell teme, profundamente, la erosión del sistema. Algunos aceptan de buen grado los ataques del postestructuralismo al marxismo pero se olvidan de que, en el mismo frente, se atacan las raíces del capitalismo, la sociedad de consumo, "el realismo y la representación, la cultura de masas y la estandarización, la gramática, la comunicación y las presiones presumiblemente todopoderosas y homogeneizantes del estado moderno"95. Así, el postmoderno ve la disolución del siste-

91. Ib., 205

92. Ib., 208

93. Cfr. Natal, D., Hacia un cristianismo postmoderno. Estudio Agustiniano 25 (1990) 15

94. HuYssen, A., Cartografía, 221

95. Ib., 226 
ma con gozo, lo que parecerá una locura al hombre del poder. "Pero si el postestructuralismo puede verse como el revenant del modernismo en forma de teoría, entonces eso también sería precisamente lo que lo convierte en postmoderno. Es un postmodernismo que se elabora así mismo no como un rechazo del modernismo, sino como una lectura retrospectiva que, en algunos casos, es completamente consciente de las limitaciones y ambiciones políticas fallidas del modernismo. El dilema del modernismo había sido su incapacidad, a pesar de sus mejores intenciones, para crear una crítica efectiva de la modernidad y la modernización burguesa" 96.

La postmodernidad defiende al hombre como sujeto. Esto puede parecer una recaída burguesa. En definitiva es el hombre concreto el que nos importa, no el colectivo, ni el sistema. Interesa la vida concreta de cada persona concreta. "Y el hecho de presentar la cuestión de la subjetividad no lleva en absoluto al estigma de ser cogido en la trampa de la ideología burguesa o pequeño-burguesa; el discurso de la subjetividad ha perdido las amarras del individualismo burgués. Ciertamente no es accidental que las cuestiones de la subjetividad y autoría hayan surgido como revancha en el texto postmoderno. Después de todo, sí importa quién habla o escribe"97. Porque a veces la muerte moderna del sujeto ha sido también la muerte del hombre y el asesinato violento o el campo de concentración. Eso no impide tomar precauciones, como la vuelta de lo sublime exige cuidado, para no recaer en los atropellos que se hicieron en su nombre, pero eso mismo ha de temerse de los metarrelatos de izquierda. El postmodernismo rechaza el modernismo estrecho de miras, no se trata de volver la vista atrás para convertirse en estatua de sal. Lo dice muy bien Huyssen: "Con todo, mi interés principal en torno al postmodernismo contemporáneo se refiere al hecho de que actúa en un campo de tensión entre la tradición y la innovación, entre la conservación y la renovación, entre la cultura de masas y el arte de élite, en el que los segundos términos ya no quedan automáticamente por encima de los primeros; un campo de tensión que ya no puede ser comprendido a través de categorías como el progreso contra la reacción, la izquierda contra la derecha, el presente contra el pasado, el modernismo contra el realismo, la abstracción contra la figuración, la vanguardia contra el Kitsch. El hecho de que tales dicotomías, que después de todo son fundamentales para la valoración clásica del modernismo, se hayan desmoronado, forma parte del desplazamiento que he intentado descubrir"98. El modernismo no es la única tabla de salva-

96. Ib., 227

97. Ib., 232

98. Ib., 236 
ción, como parece querer Habermas, ni tampoco el origen de todos los males como querían los conservadores. Por eso: "El postmodernismo está lejos de dejar obsoleto al modernismo. Al contrario, le infunde una nueva luz y se apropia de muchas de sus estrategias y técnicas estéticas incorporándolas y haciéndolas funcionar en nuevas constelaciones"99. El feminismo, el ecologismo, la subcultura, los nuevos movimientos sociales han ejercido una crítica importante al modernismo que ha llevado a la postmodernidad. Las culturas no europeas, no occidentales, deben ser acogidas por otros métodos distintos de la dominación y la conquista. Ricoeur lo había advertido hace tiempo. Del mismo modo el orientalismo debe ser algo más que fascinación o erotismo. $\mathrm{Y}$ "En conclusión, es fácil observar que una cultura postmodernista que nace a partir de estas constelaciones políticas, sociales y culturales deberá "ser un postmodernismo de resistencia, de resistencia incluso a este postmodernismo fácil al estilo del "anything goes" (cualquier cosa funciona)"... "No importa lo problemático que ello puedą resultar, el paisaje de los postmodernos nos rodea. Simultáneamente nos delimita y abre los horizontes. Constituye nuestro problema y nuestra esperanza" 100 .

La postmodernidad significa la disolución de la integración y el colapso de la historia. La postmodernidad es la disolución de la modernidad monolítica. "Pero la postmodernidad también deriva, por supuesto, de esta modernidad y, en ninguna parte es más manifiesto que en su orientación discursiva: lo que la autocrítica es para la práctica moderna, es la deconstrucción para la práctica postmoderna. Pensemos la diferencia del siguiente modo: si la "esencia" de la modernidad es el uso de métodọs, de una disciplina para atrincherarla más firmemente en el área de su competencia, entonces la "esencia" de la postmodernidad es la misma pero, precisamente, para subvertir la disciplina. El arte postmoderno "desatrinchera" su medio dado, no sólo como una actividad autónoma sino como un modo de representación con un valor referencial y/o un estatus ontológico"101.

El buen sujeto cristiano-burgués pretende conservarse a sí mismo como sea: "En la derecha, esta tendencia se manifiesta en una insistencia nostálgica en el ser fuerte y bueno, pragmático, patriarcal e ideológico en extremo. Pero las posiciones de la izquierda sólo parcialmente plantean menos problemas." 102. Para los que sufren el discreto encanto de la burguesía esa pérdida, y/o agonía y demolición del buen burgués, no es ninguna pérdida en absolu-

99. Ib., 237

100. Ib., 241

101. Foster, H., Polémicas(post)modernas. en Pico, J., Modernidad y Postmodernidad, 258

102. Ib., 260 
to. Del mismo modo el cuerpo social desea perpetuarse a sí mismo por medio de la ciencia, las leyes, las medidas administrativas, morales y filosóficas, pero todo lo humano es caduco a pesar del "mito de lo dado" y la ideología de la presencia que también había descubierto el marxismo: "Este afirma que la realidad, tal y como es dada al sujeto, está socialmente construida, es el efecto de una variedad de prácticas sociales que sirve para crear lo que Gramsci llamó "sentido común"103. Pero la verdadera cultura "popular" se enfrenta al monolitismo. Por su parte, el crítico alerta de la posibilidad del engaño, de la naturaleza retórica, de la razón filosófica y científica y de sus abusos, así como el nefasto "poder pastoral" sobre el pueblo104. Y esta es una vieja historia que conviene desenmascarar. La postmodernidad se lo ha tomado en serio. "Es la naturaleza de esta contextualización del discurso la que basa la "mundana" "incredulidad" hacia la meta-narrativa de los postestructuralistas. Su punto de partida es la siguiente propuesta: "no hay relación de poder sin la constitución correlativa de un campo de conocimiento, ni ningún conocimiento que no presuponga y constituya a la vez relaciones de poder" (Foucault, Vigilar y castigar, S.XXI, México, 1975,27). La voluntad de verdad no es sino una forma de la voluntad de poder. La gran metanarrativa filosófica fundada por Platón pertenece, como afirmó Nietzsche, a la genealogía de las formas de dominación, no a una historia epistemológica del progreso del conocimiento". ${ }^{105}$. Dado que la dominación es omnipresente no es muy fácil resistir, así también el postmoderno puede caer en la trampa de un poder alternativo que es casi el mismo poder. Para comenzar basta con la resistencia. De momento basta con salvar la vida, no dejarnos conquistar por los poderes muertos. Ya llegará el tiempo de la plenitud. Basta, ahora, que el sujeto no se deje reducir por el medio y mantenga su sensibilidad viva, por un distanciamiento irónico de la corrupción y la demolición cínica del significado que es el supremo mal de nuestra civilización. Hay que resistir a la obscenidad del poder y la dominación atreviéndose a saber (sapere aude) que el poder realmente no existe, es un fantasma en descomposición que difunde su propia muerte, un detritus de la edad moderna ${ }^{106}$ que, predica y proclama su realidad, el mundo plano que el mismo crea.

Este poder que se creía la verdadera realidad ha creado su propia apocalipsis donde han aparecido "las bestias pero sin ninguna revelación al

103. Callinicos, A., ¿Post-modernidad, post-estructuralismo, post-marxismo?, en Pico, J., Modernidad y Postmodernidad, 267

104. Ib., 281, 283. Así R. Rorty y Christofer Morris.

105. Ib., 285

106. Kroker, A., El Marx de Baudrillard, 310, 314 
final"107. Así ha llegado la desintegración de todo, incluido de la propia racionalidad, se ha roto la concordia y se cae en el autismo, y se ve la decadencia. El apocalipsis ha penetrado en las cosas, es la agonía de la realidad, de Baudrillard, y de la actual historia ${ }^{108}$. Dada la gran desestabilización postmoderna, para algunos: "La conciencia postmoderna parece haber perdido la capacidad para imaginar "otro estado de poder", con su fuerza explosiva"109. Se produce una desubstanciación de la vida, del hombre y del cuerpo social. Pero tampoco habrá que lamentarse demasiado por ello. Y ya que la sociedad nos amenaza con el apocalipsis, aquí y ahora, tendremos que tomar el asunto con cierta ironía ya que la sociedad misma que pretende amedrentar está implicada en la misma atmósfera de catástrofe y overkill. De hecho: "La ruptura con la historia que estaba firmemente identificada con el discurso del poder no fue un acto espontáneo, sino llevado a cabo bajo protesta contra el sistema funcional de la racionalidad, contra la cárcel del lenguaje, contra el sentido terrorista de seguridad, contenido en las reglas gramaticales de la conciencia social y de las instituciones. Probablemente no es casual que Baudrillard, quien quizás ha llevado la desestabilización de los significados más lejos que nadie, sea el más enérgico, incluso el más polémico defensor de la pérdida del "acontecer"110. Así el postmoderno juega con el apocalipsis y se ríe, en cierta manera, de él porque se da cuenta de que es una huida hacia adelante, una postura teatral hacia el exterior de una sociedad que ya no tiene futuro y amenaza con el clásico: o nosotros o el caos. Naturalmente preferible el caos, la postmodernidad, nuestro futuro; no el del poder muerto que pretende asustarnos con su muerte. Eso, precisamente, es lo que ya hace tiempo que esperamos, su fin. El postmoderno sabe que un sistema muere y otro mundo llega, y viene de nuevo, nunca hay fin en absoluto una generación sucede a la otra. $\mathrm{Y}$ eso es bueno, no hay nada que temer. El apocalipsis es siempre nueva vida, revelación. La muerte de la modernidad y del sistema es la vida de la postmodernidad: mors tua, vita mea, decía el clásico. Las amenazas apocalípticas del sistema nos traen sin cuidado; nos dejan indiferentes, es más nos invitan a una sonrisa irónica primero y finalmente a una solemne carcajada. La agonía de la realidad moderna, nos llena de satisfacción, no nos dan miedo las bombas, las bombas

107. RAulet, G., De la modernidad como calle de dirección única a la postmodernidad como callejón sin salida, en Pico, J., Modernidad y Postmodernidad, 322

108. SCHERPE, K.R., Dramatización y desdramatización de 'el fin': La conciencia apocalíptica de la modernidad y la post-modernidad, en PICO, J., Modernidad y Postmodernidad, 349

109. Ib., 351

110. Ib., 353 
somos nosotros los postmodernos. El miedo es el arma que siempre ha utilizado el sistema, de ahí nuestra indiferencia y nuestro pasar de esa sociedad del miedo: "Lo que es en última instancia sólo efectivo estéticamente, es una postura narrativa caracterizada por una clase de frialdad e indiferencia, se abre camino incluso donde la energía potencial de una protesta puesta en movimiento por un acto de destrucción debería ser decisiva. Es interesante, comprobar cómo Kluge se traslada a una actitud postmoderna de "la agonía en la realidad" donde noveliza su teoría social directamente: "un día la industria desapareció completamente", escribe en una de sus historias de ciencia ficción, "su realidad desapareció de un día para otro"111.

Así tampoco esperamos un acontecimiento que lo cambiará todo en su momento, la vida de cada día es el cambio. Somos cada cual el que debemos cambiar para que cambie el mundo. Lo decía San Agustín: tiempos buenos, tiempos malos, decís; los tiempos somos nosotros, seamos buenos nosotros y los tiempos serán buenos: "La bomba no nos pide ni resistencia ni resignación, sino más bien una experiencia de auto-descubrimiento. Nosotros somos la bomba. El "sujeto" occidental es hecho fructificar"112. Lo que más necesita el mundo es que seamos hombres nuevos. No debemos dejarnos fascinar por el miedo a la catástrofe, esa es hoy la principal estratagema del sistema. Pero el individuo que trabaja activa y apasionadamente por el fin, es recompensado con la promesa apocalíptica del renacimiento de la catástrofe: "Llamaría a este otro fin, el comienzo de un nuevo mundo"113. También nuestra época tiene un futuro propio que no se debe dejar arrebatar por nada ni por nadie. También aquí y ahora hay motivos definitivos para la esperanza. Y no podemos faltar a la cita que la realidad, el mundo, los hombres y mujeres de nuestro tiempo, y, por supuesto, si creemos, Dios tiene con nosotros. Esa es hoy nuestra suerte. Y también, si un postmoderno puede hablar así, nuestro deber inexcusable e inaplazable e irrenunciable.

\section{5.- Éticas y políticas postmodernas}

5.1.- Quizá haya sido B. Henri-Levy el que ha denunciado con más claridad la terrible falta de ética de los sistemas sociales y el peligro que esto constituye para la humanidad. Al final de La barbarie con rostro humano, después de denunciar al marxismo actual como opio de los pueblos y el capi-

111. Ib., 373-374

112. Ib., 376

113. Ib.,379 
talismo tecnológico como engaño científico del poder, creador de la realidad a su imagen y semejanza, terminaba así su escrito: "Ya no tenemos política, ni lengua, ni recursos. No queda otra cosa que la ética y el deber moral... Ya es hora, acaso, de escribir tratados de moral"114. Allí explicaba también el mismo autor lo que luego diría más claramente Baudrillard cuando afirmaba que "el poder crea la realidad". Decía así Henri-Levy: "De dónde procede, para comenzar, esta pregunta que formulo del modo más abrupto e inflexible: qué es exactamente la realidad y cuál es su estatuto político? Los políticos se abstienen justamente de hacerla. Viven en la certidumbre de que la realidad está poblada de cosas, de que estas cosas son fósiles, que estos fósiles son fragmentos, concreciones de la naturaleza, congelados y solidificados desde siempre; que por más que la Historia marque con sus zarpas y la pintarrajee con sus jeroglíficos, sigue lisa y lavada, vidriosa y cristalina, como un espejo sin azogue donde se refleja su voluntad; que no constituye, que no provoca problemas, porque está ahí, ante ellos, en una muda interioridad, materia pasiva y letárgica que se ofrece a sus cálculos y se abre a sus proyectos. Esta es literalmente la "Realpolitik", esta creencia en la realidad, esta piedad para con el mundo, esta naturalización de su espacio"115.

Ante el poder no hay metafísica, ni fondo, ni fundamento, ni realidad primigenia porque él es el origen de todas las cosas: "Porque el problema no reside en esto, es infinitamente más radical: el poder no se apropia el mundo, lo engendra constantemente en el conjunto de su dimensión. No expropia a los hombres sus moradas, les fija residencia, excava y fortifica sus nichos, donde, literalmente, arraigan. Lejos de desgarrar con malignidad la urdimbre de su tejido social, es el sastre que corta el paño de toda realidad. No es el mundo lo que él deshace, a reserva luego de devolverlo a hacer, sino que, al contrario, lo hace sin referente y sin precedente. Esto es más difícil de pensar, el tema más arduo de un pesimismo consecuente; no se trata de esta realidad que roe y exfolia el Amo, sino de la forma misma de la realidad que él siempre engendra; si la realidad del capital, es, como se sabe, desesperante, vano es achacar a otro sus propios sueños y esperanzas; lo propio del poder, en una sóla palabra, consiste en su función, y en su vocación de modelar y recortar la realidad en cuanto tal"116. Una vez creado el "orden" se invita a su adoración como obra de "dios" y el "dios" se hace programa y

114. Henry-Levy, B., La barbarie con rostro humano. Trad. castellana de E. Simons, Barcelona 1978, 186 y 192. Cfr. también NATAL, D., Ante la ética de la fuerza o el tema de nuestro tiempo. Estudio Agustiniano, 15 (1980) 199-223

115. HENRY-LEVY, La barbarie, 47-48

116. Ib., 50 
el programa se hace dios, dirá Glucksmann. Y así el mismo Glucksmann se pregunta, amilanado, ante los dos grandes sistemas: “¿Cómo soportar los dos extremos de la misma cadena, el horror extraordinario de los campos (de concentración) y la sorda complicidad de la sociedad ordinaria?... ¿Cómo es posible que existan los campos? ¿Cómo es posible que resistamos tan mal y tan poco?"117. El cinismo burgués y el cinismo colectivista se abrazan profundamente. Y ambos animan la voluntad de no ver. Así sus grandes relatos justifican sabiamente los regímenes sin alma: "La teoría social ayuda al bribón a blanquear sus actos a sus propios ojos y a los de los demás, para no escuchar reproches o maldiciones sino alabanzas y testimonios de respeto. Así es como los inquisidores se apoyan en el cristianismo, los conquistadores en la exaltación de la patria, los colonizadores en la civilización, los nazis en la raza, los jacobinos (de ayer y de hoy) en la igualdad, la fraternidad y la felicidad de las generaciones futuras..." (El Archipiélago Gulag, t.I, 1313-132"118. Glucksmann cree que los campos de concentración tienen que ver con la explotación del trabajo y el encierro de los hombres. "Empezamos a sospechar: si Europa occidental ha dejado que se desarrollaran los campos sin reaccionar demasiado es porque los había inventado sin estremecerse. La racionalización económica del encierro y la rentabilización del trabajo forzado acompaña la guerra del 14-18"119.

En los maestros pensadores, el sistema une la autoridad de la ciencia y la ciencia de la autoridad, se elabora un arte de gobernar, se reduce a la plebe, se asegura su complicidad y la impotencia de las élites ${ }^{120}$.

Por su parte el ideal burgués ha perdido sus garantías y "no designa ya nada positivo", no tiene ya nada que decir a las gentes de nuestro tiempo porque se ha descubierto también su propia violencia ${ }^{121}$. Los propios movimientos de liberación han secretado regímenes de opresión ${ }^{122}$. La lógica colonial continua en sus contrarios. La libertad es otra cosa que "la potestad de cambiar de cadenas" y la instalación en el feliz o infernal mundo cotidiano.

Michel Foucault después de afirmar que los sistemas sociales tradicionales no daban ninguna orientación para la situación actual, ni a la derecha ni a

117. Glucksmann, A., La cocinera y el devorador de hombres. Ensayo sobre el Estado, el marxismo y los campos de concentración. Madrágora, Barcelona 1977, 15 y 16

118. Ib., 36

119. Ib., 69

120. Ib., 165

121. Glucksmann, A., La estupidez. Ideologías del postmodernismo. Trad. castellana de Península, Barcelona 1988, 111

122. Finkielkraut, A., La derrota del pensamiento. Trad. castellana de Anagrama, Barcelona $19872^{\mathrm{a}}, 75$ 
la izquierda, sorprendió a sus discípulos con una llamada a la ética y al "cuidado de sí mismo". Esta tarea es un trabajo de uno mismo sobre uno mismo que debe llevar a la conversión frente al deseo de poder y de fuerza, propia del tirano o del hombre rico, para evitar el abuso del poder ${ }^{123}$. Es necesario liberarse a sí mismo, fundarse a sí mismo en libertad para luego llegar a una sociedad de liberación. En otro caso todo fracasará y funcionará según es costumbre. Quizá Foucault mismo sospechaba que el poder social actual se impone sistemáticamente a todo incluido su propio pensamiento. Pues como había denunciado ya Baudrillard él sería como "el espejo de los poderes que describe"124.Quedando él mismo como el último dinosaurio de la época clásica que en modo alguno ataca el principio de realidad que es el principio de la fuerza ${ }^{125}$, de la industria y el consumo ${ }^{126}$ producidos por el poder ${ }^{127}$, y que invita a su propio culto para que sea posible no descubrir sus fallas, su agonía, su disolución y su vacío de poder que trata de llenar vanamente con su energía de lo real que nos da seguridad ${ }^{128}$ aunque esté preñada de muerte y se reduzca a falsa razón social, ya difunta, que puja con vanos deseos por resucitar violentamente ${ }^{129}$. Es el poder que ya no es lo que era y por eso queda al descubierto y puede ser denunciado. Foucault y los postmodernos lo han hecho admirablemente; quizá a su vez fascinados por múltiples poderes, como Schopenhauer, como Nietzsche. Por su parte Baudrillard puede darnos la impresión de que las cosas son demasiado fáciles o simplemente muy sencillas de cambiar, mientras que Foucault nos obligaría a entrar mucho más a fondo en lo personal y lo social. Hay que cuidarse a sí mismo porque la liberación sólo es posible si a la vez es personal y social y viceversa. Hay que comenzar a vivir de persona a persona y no de persona a personal (Goodmann), como hasta ahora, pues en ese caso el buen burgués segui-

123. Foucault, M., L'éthique du souci de soi, comme pratique de liberté. Entretien avec F. Ewald et R. Betancourt. Concordia 6 (1984) 104 y 115. Cfr. también Foucault, M., Le souci de soi. Histoire de la sexualité 3. Gallimard, Paris 1984

124. Baudrillard, J., Olvidar Foucault. Traduc. castellana de Pre-textos, Valencia 1978,8 y ss.

125. Ib., 12, 13 y 57: "El poder es un principio irreversible de organización que fabrica lo real, cada vez más realidad".

126. Ib., 32 y 33

127. Ib., 46

128. Ib., 66-67 y 65: "Es el vacío lo que hay detrás del poder, en el corazón mismo del poder, en el corazón mismo de la producción, y el que les da hoy un último destello de realidad"... "Porque el secreto del poder es el mismo que el del secreto: que no existe". Y ese fue el secreto de los grandes políticos (ib. 86) saber que el poder no existe, es un fantasma que la gente persigue.

129. Ib., $90-91$ 
rá plácidamente su camino al cambiar de una dogmática oficialista a una dogmática individualista. Es necesario ir más al fondo de la situación con un nuevo proyecto social y comunitario en el que se asuma realmente la responsabilidad del nuevo futuro. Lo otro sería pura creencia mágica en que se puede cambiar algo sin hacer realmente nada. Es nada menos que una nueva humanidad y una nueva cultura lo que hemos de crear y esta tarea en modo alguno va a ser evidentemente fácil. Foucault nos ha descubierto la falsedad de las cosas la mentira de los hechos, el engaño y la industria de las conciencias y la fascinación del poder. El mal se ha introducido en nuestra propia vida, en nuestro propio corazón, y está como en todas partes y no va a ser fácil liberarse de él. El mismo saber es poder y todas las instituciones están permeadas de su violencia. Nadie es ajeno a esta enfermedad como nadie es ajeno a este mundo. Sería necesaria una nueva humanidad, descubrir lo mejor de nosotros mismos, sin miedo alguno al hombre nuevo, ni a una nueva religión ajena a nuestra fiebre de poder.

El poder construye su propia casa a través de sus instituciones y de sus archivos, así el poder se realiza como sustancia de la historia y construye su propia realidad. Por eso "desde Kant el papel de la filosofía es impedir que la razón exceda los límites de lo que viene dado por la experiencia; pero también desde entonces -es decir a partir del desarrollo del Estado Moderno y de la gestión política de la sociedad- la filosofía ha tenido también por función vigilar los poderes excesivos de la racionalidad política. Y es mucho pedirle"130. Los excesos del poder, su falta de respeto y de ética son tan evidentes según Foucault, que no hacía falta esperar a los campos de concentración ni mucho menos. Una vez convertido el hombre en "hombre objeto". de la industria, de la biología y de la razón dominante todo lo demás se nos dará por añadidura. El mismo Estado se convierte en pastor despótico del hombre que inmola a la humanidad ${ }^{131}$ y la administra a su aire. Por eso Foucault nos enseñó la resistencia permanente contra la opresión en todas partes, nos hizo saber que el ser es fundamental contra el poder y en ese sentido "Afirmaba el carácter ineludible de la resistencia individual a la opresión"132. Así se llama al hombre a la libertad, a formarse a sí mismo, "a la construcción del sujeto moral, ... o mejor dicho, la conciencia de que somos sujetos mora-

130. Foucault, M., Porqué hay que estudiar el poder: la cuestión del sujeto, en Liberación $6(30.13 .1984) 4$

131. Ib., 8

132. NEGRI, T., Tres encuentros con Foucault, Liberación 6,10

133. Olabuenaga, A., De la política a la ética, Liberación 6,12

134. AlbIAC, G., Stultifera Navis, Liberación 6, 17 
les"133. Queremos así abandonar las grandes y pequeñas coacciones de la dramática historia humana que ha convertido al hombre, falto de resistencia, en un grávido fantasma de servidumbre y sumisión ${ }^{134}$. Necesitamos preservar nuestra libertad, investigar las astucias del poder, romper la jaula de hierro y rescatar al hombre de sus diversas violencias brutales, burocráticas y/o cotidianas ${ }^{135}$, para que nuestra vida deje de ser una vida extraordinariamente bien administrada y comience a ser vida.

De hecho, tras el combate aparentemente neutral de la historia, escuchamos los rumores de la batalla, de las fuerzas de sumisión que "bajo la máscara de nuestro yo, nos prohiben toda identidad"136. Así llevan consigo al individuo para disolverlo en la normalidad y la continuidad universal. Es el poder presente en todas partes y que en todas partes se da y en todo el mundo se ejerce; la burguesía no es tan tonta como creen algunos ingenuos. El poder produce su propia verdad que enmascara la dominación, pues no siempre domina por la represión. "Lo que hace que el poder agarre, que se le acepte, es simplemente que no pesa solamente como una fuerza que dice no, sino que de hecho la atraviesa, produce cosas, induce placer, forma saber, produce discursos; es preciso considerarlo como una red productiva que atraviesa todo el cuerpo social más que como una instancia negativa que tiene como función reprimir"137. El poder no solamente produce la verdad, sino que tiene su propio régimen de verdad, según el reglamento del poder: "Cada sociedad tiene su régimen de verdad, su "política general de la verdad": es decir, los tipos de discursos que ella acoge y hace funcionar como verdaderos; los mecanismos y las instancias que permiten distinguir los enunciados verdaderos o falsos, la manera de sancionar unos y otros; las técnicas y los procedimientos que son valorizados para la obtención de la verdad; el estatuto de aquellos encargados de decir qué es lo que funciona como verdadero"138. Entonces la cuestión política primera no es la ideología, el error o la conciencia alienada sino "la verdad misma".

La prisión es ya el poder al desnudo, se trata de un mecanismo de extensión del poder normalizando todo a su imagen y semejanza por medio de la justicia que crea el hombre disciplinado y la humanidad universal abstracta según diversas estrategias de marginación, atracción y represión, que pretenden camuflar la batalla del poder y por tanto no nos dejan ver ni describen bien: "La formación de las blanduras insidiosas, de las maldades poco confe-

135. Alvarez URIA, F., Romper la jaula de hierro, Liberación 6,26

136. Foucault, M., Microfisica del poder. La piqueta, Madrid 19792a 27

137. Ib., 182

138. Ib., 187 
sables, de las pequeñas astucias, de los procedimientos calendados, de las técnicas, de las "ciencias" a fin de cuentas, que permiten la fabricación del individuo disciplinario. En esta humanidad central y centralizada, efecto e instrumento de relaciones de poder complejas, cuerpos y fuerzas sometidas por dispositivos de "encarcelamiento" múltiples, objetos para discursos que son ellos mismos elementos de esta estrategia, hay que oír el estruendo de la batallas"139. La verdad se queda en instrumento de la política y la tortura aparece como prueba judicial y verdad brutal del alma. ${ }^{140}$.

La falta de ética del poder es la que hace a los ilegales héroes del pueblo ${ }^{141}$ y a los bandidos, amigos de los pobres, que tienen a gala la ilegalidad y ponen en evidencia el sistema. Por otra parte el poder controla el cuerpo social y humano por medio de la disciplina y el rango. Así el hombre es un producto de la disciplina: militar, judicial, moral, escolar, médica, espiritual, y "el sistema se halla en el centro de los procedimientos que constituyen al individuo como objeto y efecto del poder, como efecto y objeto del saber"142. Así el poder crea por medio de la ciencia y su investigación los hechos que son los hechos.143. Y el trabajo, que es lo más efectivo, llena el vacío de toda clase de bienes en la sociedad dominada y sometida; "El trabajo es la providencia de los pueblos modernos; hace en ellos las veces de moral, llena el vacío de las creencias y pasa por ser el principio de todo bien. El trabajo debía ser la religión de las prisiones. A una sociedad-máquina le eran precisos medios de reforma puramente mecánicos"144.

La manera como "la justicia" enmascara el poder es uno de los mayores éxitos de la dominación burguesa, sólo inferior a la destrucción de la Universidad, por eso el anarquismo siempre quiso reivindicar en la revolución los ilegalismos populares. La sociedad alimenta sus propios delincuentes a los que consigue castigar con "naturalidad" y "autentificar" como delincuentes por la ciencia judicial. La delincuencia es una justificación de las clases dominantes a las que los jueces "Ayudan en la medida de sus medios a la constitución de la delincuencia, es decir, a la diferenciación de los ilegalismos, al control, a la colonización y a la utilización de algunos de ellos por el ilegalismo de la clase dominante"145.

139. Foucault, M., Vigilar y castigar. Nacimiento de la prisión. Trad. castellana S. XXI edics. Madrid 1984, $4^{\mathrm{a}}$, 314

140. Ib., 36

141. Ib., 91

142. Ib., 197

143. Ib., 228

144. Ib., 245-246

145. Ib., 288 
De esta forma, tan cruda, denunciaba Foucault al cínico buen burgués tan bien considerado, normalmente, por otros: "Era necesario ser tan ingenuo como Baudelaire para imaginarse que la burguesía es tan tonta y gazmoña. Es inteligente y cínica. Basta leer lo que decía sobre sí misma, y mucho mejor, sobre los demás ${ }^{146}$. Althusser lo había percibido también con mucha claridad cuando decía: "En la Crítica al Programa de Gotha, Marx escribió: "Los burgueses tienen excelentes razones para atribuir al trabajo (humano) esta sobrenatural potencia de creación. ¿Por qué? Porque hạciendo creer a los "hombres" que ellos "hacen historia", que "el trabajo es la fuente de toda riqueza y de toda cultura", los burgueses silencian la potencia de la "naturaleza"; dicho de otro modo, silencian la importancia decisiva de las condiciones naturales, materiales del trabajo humano. ¿Y por qué los burgueses guardan silencio acerca de estas condiciones naturales-materiales del trabajo? Muy sencillamente, porque ellos las detentan. Los burgueses no son tan tontos"147. Althusser sabe muy bien la función ideológica del humanismo burgués en toda la cuestión: "Que la burguesía, en su ideología, haga silencio acerca de las relaciones de producción y la lucha de clases, para exaltar la "expansión" y la "productividad" al mismo tiempo que el Hombre y la libertad, es su asunto, y ello está en orden, su orden, puesto que ese silencio le sirve y permite a la pareja economicismo/humanismo, que expresa el punto de vista burgués, trabajar para disimular, asegurar y reproducir las relaciones de explotación"148. Esa misma función es la que desarrolla el derecho burgués a partir del humanismo burgués en el que sólo el buen burgués es hombre y lo demás es delincuencia: "Pero también es cierto, al mismo tiempo, que el reverso orgánico, la "cobertura", la coartada y el "punto de honor" obligados de este economismo son el humanismo o liberalismo burgués, puesto que tienen sus bases en las categorías del Derecho burgués y de la ideología jurídica materialmente indispensable para el funcionamiento del Derecho burgués: la libertad de la Persona, vale decir, en principio, la libre disposición de sí, la propiedad de sí, de su voluntad y de su cuerpo (¡el proletario: Persona "libre" de venderse!), y de sus bienes (la propiedad privada: la verdadera, que derogó a los otros: la de los medios de producción)"149.

Foucault había reconocido perfectamente la estrategia del humanismo burgués: "la emergencia del "hombre" como objeto de un saber por medio

146. Foucault, M., Microfisica del poder, 95

147. Althusser, L., Para una crítica de la práctica teórica. Respuesta a John Lewis. Trad. castellana de S. XXI edcs., Madrid 1974, 53

148. Ib., 97

149. Ib., 95 
del cual se vehicula una nueva forma de poder aquella que caracteriza nuestro Orden Burgués: la normalización"150. Esta burda utilización llevará a una crisis incomparable, en occidente, de Europa, "como forma de vida espiritual", de sus valores y de su cultura burguesa y ahí está la postmodernidad. Lo ha dicho muy bien M. Morey: "Era preciso que el "hombre" del humanismo burgués muriera, que se desligara del hombre concreto de ese ahormamiento en el que el saber lo apresaba (como el vuelo de la mosca queda congelado en la gota de ámbar, según la conocida metáfora de Lacan), para que el vuelo concreto, azaroso y fecundo del pensar pudiera tener de nuevo un lugar"151. Este, reclama una nueva transvaloración en la que los mitos que custodian el orden burgués sean puestos en cuestión de nuevo, se desanude la unión entre saber y poder, según el modo actual, y se desenmascare la unión entre los errores y los horrores que muestran los infiernos y sufrimiento de la historia humana152 y el orden laboral occidental con su encierro así como el despojo del hombre: "Es decir: que es sobre la negatividad del hombre concreto expropiado por el saber que surge el hombre moderno -hombre que se conoce y conoce a los hombres al precio de no poder reconocerse" 153 . Este modelo del hombre es una creación moderna y tiende a desaparecer con la postmodernidad. El hombre disuelto por las ciencias humanas de la modernidad está listo y a punto para resucitar en la postmodernidad dada la crisis de la moral de las ciencias "humanas" que lo crearon, con sus propias "turbulencias", no de manera neutral, según se quiere hacer creer, sino en una batalla perpetua por la mal llamada "normalización" de la vida humana por medio de expertos, juristas, médicos, psicólogos y demás "científicos", guardianes del "Orden burgués: un poder múltiple, automático y anónimo, enormemente meticuloso, pero discreto..."154. Este orden exporta a la vida cotidiana la vida de la prisión y por eso nos invita a emanciparnos en la sexualidad cínica burguesa y así es la "ironía de este dispositivo: nos hace creer que en él está en juego nuestra "liberación"155. Se trata de un timo, del mismo orden que no merece más comentario...

La postmodernidad propone una ética de lo bueno que no es impositiva ni de las fuerzas del orden, atiende a la vida de cada día y devuelve la palabra al propio hombre del pueblo. "En consecuencia, ésta (revolución) pre-

150. tomado de Foucault, M., Maladie Mentale et Personnalité, citado por MOREY, M., Lectura de Foucault, Taurus, Madrid 1983, 26

151. Morey, M., Lectura de Foucault, 18

152. Ib., $48,53-54$

153. Ib., 113

154. Ib., 289, 268-269

155. Ib., 353. Se trata de un texto de Foucault, M., Vigilar y castigar. 
tende llevar a término una especie de redención que haga justicia -es decir, que vuelva a dar la palabra- a todo aquello que ha sido excluido y olvidado en la historia lineal de los vencedores"156. Esta piedad y este respeto hacia el hombre concreto es lo contrario del poder disciplinario en el cual la desgracia es momento de presa y despojo. Y así como Camus vio en La Peste que en el hombre "hay más cosas dignas de admiración que de desprecio", "el poder disciplinario, por el contrario, buscó en el modelo excepcional de La Peste, la prueba y la magnificación del sistema disciplinario, apropiándose del cuerpo entero de la Ciudad y haciendo de ella un teatro del Orden"157. Pero cada uno encuentra en la realidad lo que busca y ve en el mundo lo que él es. El postmoderno recoge al último hombre herido en el camino y trata de salvar esa vida. Y eso es la revolución: "La piedad por estos despojos representa el único verdadero motivo de la revolución, más que cualquier proyecto presuntamente legitimado en nombre del derecho natural o del curso necesario de la historia"158, que ha querido ser historia de los vencedores y no historia de la responsabilidad y del respeto; pero el futuro es de la responsabilidad y de la delicadeza y ese es "el debilitamiento que caracteriza al hombre de gobierno responsable. En él se manifiesta el recuerdo de una filosofía de la renuncia al predominio del sujeto avasallador" 159 . Ciertamente, en este sentido, lo postmoderno es fruición, gozo de la vida, frente al funcionalismo y al mandato ${ }^{160}$ y el reduccionismo fácil y avasallador, aniquilador del hombre en la modernidad.

5.2.- T. W. Adorno lo había advertido dramáticamente: “Toda cultura después de Auschwitz, junto con la crítica contra ella, es basura"161. La utilización del hombre, para provecho individual, y su cosificación integradora se encargan fácilmente de todo lo demás: "El genocidio es la integración absoluta, que cuece en todas partes donde los hombres son homogeneizados, pulidos -como se decía en el ejército- hasta ser borrado literalmente del mapa como anomalías del concepto, de su nulidad total y absoluta. Auschwitz confirma la teoría filosófica que equipara la pura identidad con la muerte"... "Cuando en el campo de concentración los sádicos anunciaban a sus víctimas: "mañana te serpentearás como humo de esa chimenea al cielo", eran exponentes de la indiferencia por la vida individual a que tiende la historia. En efecto, el individuo es ya en su libertad formal tan disponible y sustituible como lo fue bajo las patadas de sus liquidadores. Pero desde el

156. Vattimo, G., A. Rovatti, El pensamiento débil. Cátedra. Madrid 1988, 23

157. MOREY, M., Lectura de Foucault, 294

158. Vatrimo, G., A. Rovatri, El pensamiento débil, 41

159. Ib., $141 ; 158$

160. VatTimo, G., El fin de la Modernidad, Gedisa, Barcelona 1986, 155 y 156 
momento en que el individuo vive en un mundo cuya ley es el provecho individual universal, y por tanto, no posee más que este yo convertido en indiferente, la realización de la tendencia desde antiguo familiar es a la vez lo más espantoso"162. La frialdad burguesa dirá que "no es para tanto", pero quien se salve a consta de los demás no podrá ya olvidar nunca su bochorno y su vergüenza, dic̀e Adorno. Entre nosotros, Ortega lo recordaba con motivo de la muerte de Unamuno. La vergüenza inundará a la humanidad mucho más que el miedo. Aunque bajo el hechizo egoísta ningún hombre "será capaz de amar y, por consiguiente, todos se seguirán creyendo demasiado poco amados"163. Cuando B. Shaw enseñó a un mendigo que le pedía limosna, su carnet de "periodista" revelaba la propia conciencia cínica y burguesa ante la vida y el sufrimiento humano, nos dirá Adorno.

Pero estas cosas no ocurren así porque sí, primero se nos invita a resignarnos ante la realidad, después huimos de ella irresponsablemente, finalmente nos convencemos de que no es posible hacer nada que valga la pena. Nos hacemos una idea del mundo que no toque la realidad, a nuestra medida, según la norma de nuestro interés. Pero si algo es el pensamiento sería precisamente capacidad de resistir a lo que se impone por sí mismo y sensibilidad ante el dolor y la desgracia humana: "Lo que hay de doloroso en la dialéctica es el dolor, elevado a concepto, por la pobreza de este mundo. A ésta tiene que plegarse el pensamiento si no quiere degradar de nuevo la concreción a la ideología en que de hecho está empezando a convertirse"164. Si esto ocurriera, el ansia del orden ahogaría el deseo de emancipación. El sistema fácilmente arrasará con todo. El pensamiento debe emplearse a fondo para evitar ser administrado por un pretendido sentido común universal. Hoy más que nunca se necesitan personas ajenas a la opresión social e indigeribles por la masa y la retórica del poder que crea la estructura categorial y social que conviene al "andamiaje de la situación establecida". Se necesitan hombres, individuales aunque no individualistas: "La exclusión del individuo no producirá un sujeto superior, purificado de las escorias de lo imprevisible, sino sólo un repetidor inconsciente de lo que se le fuese programando. En los paises del Este el cortocircuito teórico en este punto ha servido de pretexto a la opresión colectiva. Incluso cuando el partido está ciego o aterrorizado, su número de afiliados le da a priori superioridad cognoscitiva sobre cualquier 367

161. Adorno, T.W., Dialéctica Negativa. Trad. castellana de Taurus eds., Madrid 1975,

162. Ib., 362

163. Ib., 363

164. Ib., 14 y 27 
individuo... La fantasía exacta de un disidente puede ver más que mil ojos a los que les han calado las gafas rosadas de la unidad y que en consecuencia reducen y confunden todo a lo que perciben con la verdad universal"165. Al otro lado del sentido común de Babit, olvidándose del hombre, el pensamiento confunde la sociedad del negocio (los ídolos del mercado) con la realidad misma (ens realissimum, dice Adorno) y así se aleja inefablemente de la vida: "Doctrinas que se evaden del cosmos sin importarles el sujeto son, al igual que la filosofía del ser, más compatibles con la endurecida constitución del mundo actual y las oportunidades de éxito que ofrece que una brizna de reflexión subjetiva sobre sí mismo y el propio cautiverio"166. Así la libertad, de la que tanto se ha hablado, se convirtió en un fantasma: "La libertad no pasó en general de la ideología, los hombres son impotentes ante el sistema e incapaces de determinar racionalmente su vida y la de la totalidad"167. Tal es el vértigo y el terror de una sociedad omnipotente, libre en apariencia, y con un bienestar abundante. El hombre bien educado no se mancha con la realidad, tiene sus buenos agentes que hacen fielmente el trabajo sucio en su lugar, de modo que su mundo feliz no sea en nada molestado por el sufrimiento "ajeno". Pero como dice Adorno: "Aunque no sea más que por vergüenza, la filosofía debe enfrentarse con la idea de Georg Simmel: lo asombrosamente poco que se le nota a su historia los sufrimientos de la humanidad"168.

La reglamentación social y "científica" del pensamiento le impide educadamente acercarse a la realidad cuando ésta es hiriente y nada agradable para el hombre prepotente. Pero así descuida su propio mundo y olvida felizmente su esclavitud: "Lo que hace el sujeto está dominado por lo que se figura dominar. Con la sublimación desesperada de sí mismo reacciona a la experiencia de su impotencia, que le impide la autoreflexión; la conciencia absoluta carece de conciencia"169. Así, la reducción del mundo a la medida del hombre se convierte en "reductio hominis" y esclavización del hombre, puesta a la cuenta de Dios autor de la "naturaleza". De tan simple modo, se afirma que todo es bueno y está bien y se intenta "disuadir a la experiencia de que existe el dolor"170. Y se "produce el silencio espiritual, sin paz, de la administración integral"171. Pero la teoría "no puede hacerse la tonta" ante la

165. Ib., 52

166. Ib., 72

167. Ib., 93

168. Ib., 156

169. Ib., 182

170. Ib., 204

171. Ib., 206 
situación actual; sobre todo cuando los privilegiados de la libertad se alegran de que los demás no estén preparados para ella, mientras la sociedad anima a los hombres a hacer apología de la "estructura pervertida" y la coacción social en nombre de su libertad y de la ciencia, especialmente, cunde: "El interés de los sujetos por estar atendidos paraliza todo lo que sea interés por una libertad cuyo desamparo temen. No sólo la invocación de la libertad, sino ya sólo nombrarla suena a retórica" ${ }^{172}$. Se olvida que todo individuo está sujeto al reglamento del orden social y "al programa archiburgués de la absoluta dominación de la naturaleza"173. La opresión del conjunto necesita la libertad para echar la culpa al hombre de los males de la vida y lo poco de vida que hay en lo que llamamos vivir: "La tesis del libre albedrío carga a los individuos subordinados la injusticia social ante la que son impotentes, y les humilla constantemente con desiderata ante los que tienen que fracasar; en cambio, la tesis del determinismo prolonga metafísicamente la hegemonía de lo dado, se declara inmutable y anima al individuo -cuando él no está dispuesto a ello ya de por sí- a echarse cuerpo a tierra, puesto que al fin y al cabo no le queda otro remedio"174. Y, en definitiva,: "Nunca ha habido más libertad que la voluntad que tuvieron los hombres de liberarse"175. La presión de los poderes fácticos está asegurada también a través de los mandatos morales. Por eso, decía San Agustín, y es teológica y realmente seguro que: La voluntad humana en tanto es libre en cuanto se libera. El honrado ciudadano tiene que atenerse a la honradez oficial para seguir siendo honrado. De lo contrario: "La crítica del superego tendría que convertirse en crítica de la sociedad que lo produce, si enmudece ante ella, es que se pliega a la norma social dominante... El mundo como es se convierte en la única ideología, y los hombres en sus partes integrantes" ${ }^{176}$. En una sociedad sin libertad la conciencia moral fácilmente de-genera en infamia al rendirse ante los hechos que encubren la dominación que reduce el hombre a su función: "La miseria de la división del trabajo queda hipostasiada como una virtud en el concepto de función, de modo que el sujeto se vuelva a prescribir por sí mismo aquello a lo que la sociedad le condena... La dureza cosista de la propia identidad y su capacidad de sacrificio y disponibilidad para los papeles que requiere de ella la sociedad, son cómplices... La situación actual es demoledora: para mantener la identidad abstracta, la desnuda supervivencia, hay que perder la identidad"177. Así el individualista se engaña a sí mismo y acepta la represión

172. Ib., 215

173. Ib., 243

174. Ib., 262

175. Ib., 263

176. Ib., 272

177. Ib., 276 
universal. Se dice que los hombres sean libres para que no lo sean: "Colectivismo e individualismo se complementan mutuamente en la mentira"178. Se hace creer al hombre que es libre y espontáneo, se ha interiorizado la dominación, ya no es posible hacer nada para que las cosas cambien, por eso se cae en la indiferencia y la frialdad humana: "Una vez que el hombre interior es absolutizado y se elimina de él toda intervención específica sobre la realidad, no puede sino degenerar en el absoluto indiferentismo"179. Lo que parece lo mejor degenera en lo peor, corruptio optimi pessima. La desigualdad se camufla de igualdad y el "narcisista satisfecho", individualista, se presenta como realización y felicidad del individuo. La sociedad se siente autoconfirmada y de acuerdo con la providencia: "El nombre del "Espíritu universal" no hace más que afirmar y personalizar al espíritu tal como éste ha sido en sí desde siempre. En él se adora la sociedad a sí misma transfigurando su coacción en omnipotencia"180. Así se diviniza la historia y el Estado, y el pensamiento se ontologiza, se pliega a la realidad social dominante. "La presión que ejerce la afirmación sobre lo real, que se le opone, engrosa incansablemente la presión real que la universalidad infringe al sujeto como su negación... Pero cuando la máxima clasicista pregona ostentosamente la verdad sobre una identidad que aún no hace más que tratar de conseguir, confiesa su propia falsedad: la de "la letra con sangre entra", tanto en sentido literal como en el figurado del mandamiento inapelable al someterse" 181.

$\mathrm{El}$ individuo pierde su propia identidad, queda hechizado por lo que existe: "El individuo se sobrevive" 182 . Al no poderse realizar en la sociedad auténtica, el individuo se cierra en la realización "psicológica". La felicidad, entonces, no es más que un fantasma de felicidad puesto que:

"La felicidad no puede comenzar más que con la liberación a partir de la particularidad como principio universal; la felicidad individual, como es posible aquí y ahora, es incompatible con ellas"183. Entonces la felicidad es la felicidad y la eternidad de la destrucción y de la dominación. Por eso nos reclama lo efímero y la caducidad para salir del círculo infernal de la violencia. Pero esto no significa que "todo vale" y que "todo es relativo", sino que el espacio y el tiempo postmodernos nos liberan del tutelaje de la sociedad del absoluto-absolutista niveladora universal. "Pero la hora crítica de Kunst ha llegado ahora. Aquellos que viven en una temporalidad postmoderna,

178. Ib., 281

179. Ib., 293

180. Ib., $314,317,333$

181. Ib., 334

182. Ib., 342,343

183. Ib., 352 
que están preocupados por un tipo particular de actividad artística (o de varios), el cual gratifica su contingencia y les ayuda a convertirse en destino, no pueden ser molestados por los imperativos de la espera homogeneizada como autoridad. En este sentido, el postmoderno es el heredero directo del antiautoritarismo de la última generación modernista"184. Ahora la marginalidad recibe una palabra de aliento mientras tiemblan los sistemas de siempre en la vida, en la educación y en la buena salud. El lado negativo de la postmodernidad podría situarse en: "El solipsismo del placer, un ostentoso (y a menudo cínico) relativismo absoluto, puede ser uno de los productos de la nueva constelación" 185 .

Pero detrás de la ética postmoderna tenemos la siguiente convicción: Nuestro mundo es problemático, pero a la vez tiene su dignidad que si la destruimos nos dejará sin rastro de libertad e incluso puede que de vida. Hay que ganar la emancipación poco a poco y día a día, no hay milagros repentinos como en la ética moderna del todo o nada donde impera la fuerza, el interés y la conformidad: "Incluso si asumimos que las reglas del juego son valiosas y merecen ser practicadas, la gente que ha sido socializada en medio de una Sittlichkeit tan intolerante, aunque benigna, será incapaz de hacer una elección moral o incluso de mantenerse honesta cuando la suerte está echada. El espíritu de semejante pseudohegelianismo moderado se desenmascara con la historia del cocinero: las personas que en su tierra se comportan como sujetos amables y liberales se convierten en bestias racistas y asesinas en las colonias"186.

Por otra parte, la diversidad de cosmovisiones y diversos modelos éticos no significan sin más que "todo vale", ni que falte un cierto nivel ético y valioso para todos. "Si prevalecen tanto la autonomía moral como el pluralismo en visiones del mundo, no todo está permitido, incluso si hay un Dios para unos y no lo hay para otros, ya que ciertas acciones siguen estando prohibidas para todos, dado que todos son capaces de distinguir el bien del mal en términos de ethos común"187. La ética postmoderna es un espacio personal para los que tienen problemas con la modernidad y algunos de sus ideales. Lo mismo ocurre con el modelo social occidental en general. "Los que han elegido vivir en la postmodernidad viven, no obstante, entre modernos y postmodernos. Porque la misma base de la postmodernidad consiste en con-

184. Feher, F., A., Heller, Políticas postmodernas. Ensayos de crítica cultural. Península, Barcelona 1989, 15

185. Ib., 22

186. Ib., 30

187. Ib., 34 
templar el mundo como una pluralidad de espacios y temporalidades heterogéneas. Así, la postmodernidad puede sólo definirse en el seno de esta pluralidad, en contra de esos otros heterogéneos"188.

Políticamente la postmodernidad se encuentra entre el "capitalismo popular" de la extrema derecha anglosajona y el mayo del 68 de la extrema izquierda. Se trata de un reciclaje de teorías, del marxismo, de la religión, la cientificidad, el evolucionismo y el final de la ideología. Pero para el postmoderno, en todo ello, hay sus más y sus menos, pues todavía se aspirará al paraíso en la tierra, a la sociedad transparente, pues los muertos resucitan, aunque con un nuevo realismo. "La dominante temporalidad de la postmodernidad tiene también serias implicaciones políticas. Cualquier tipo de política redentora es incompatible con la condición política postmoderna. Porque las pretensiones mesiánicas y las expectativas significan muchísimo más que meramente cuestionar y someter a prueba la modernidad, lo cual es la tarea que ha autoadoptado la postmodernidad. La limitación postmoderna hacia el presente como nuestra única eternidad también excluye los experimentos con "saltos en la nada", es decir, los intentos de la trascendencia absoluta de la modernidad. Al mismo tiempo, esta condición política postmoderna se siente terriblemente incómoda con las ideas utópicas, incluso de tipo mesiánico, las cuales la hacen vulnerable a los compromisos fáciles con el presente y susceptible, a la vez, a "los mitos del fin del mundo" y a los miedos colectivos que se derivan de la pérdida del futuro"189.

La caída de los excesos del universalismo y las generalizaciones pueden facilitar la realización de la vida concreta, pero también pueden llevar a la tentación de hacer promesas excesivamente optimistas en una sociedad totalmente transparente, un paraíso en la tierra y una vida sin límites temporales ni humanos lo cual sería un nuevo engaño aunque el ideal sea importante ${ }^{190}$. El sincretismo religioso consecuente no haría sino emborronar más la situación, ante la pérdida de fe en el liberalismo y el marxismo. Por eso la postmodernidad debe exigir unos minima moralia para no caer en la desmoralización total: "Si el total relativismo moral, que es innegablemente una de las opciones de la postmodernidad, domina en ella, incluso la evaluación de las deportaciones en masa y el genocidio se convierte en una cuestión de gusto. (Que esto es mucho más que una posibilidad teórica queda probado por el "fascismo postmoderno" de Le Pen)"191.

188. Ib., 137

189. Ib., 152

190. Ib., 155

191. Ib., 159-160 
La persona no puede autoglorificarse a sí misma y convertirse sin más en el centro del mundo, ni es posible considerar todas las demandas de libertad mejor como pura retórica de autocomplacencia. No se trata de acabar con todo ni de empezar todo de nuevo, hay que ir paso a paso. Ya no es posible creer en las políticas redentoras, ni marxistas, ni anarquistas, ni capitalistas donde todo se crearía ex novo como un nuevo absolutismo. "Estos y otros proyectos similares han sido catalogados de ejemplos de políticas redentoras por Ferenc Féher. Una política redentora es aquella en la cual un único gesto final es considerado el portador de una redención suprema, tanto para la sociedad como para cada uno de sus miembros"... "Es esta pérdida de relevancia del paradigma redentor la que ha llevado a muchos a la desesperación"192. Normalmente las cosas no ocurren así, de la nóche a la mañana, como si todo dependiera de un centro o elemento mágico que trasformara todo de repente; por el contrario, las relaciones son múltiples y muy diversas entre los distintos elementos y momentos de la realidad: "Debido precisamente al carácter descentrado del sistema social, las acciones emancipadoras no tienen que centrarse en el cambio de un único centro dominante y omnímodo, sino que deben llevarse a cabo en todos los sistemas y subsistemas, en todas las esferas de la sociedad, incluidas en la vida cotidiana, en este contexto, la acción emancipadora se vuelve difusa"193.

El hombre postmoderno aspira también a una mayor autodeterminación y a una vida mejor, si no fuera así caería en la rutina y la comodidad del presente; pero la persona "tiene también un propósito más allá de la autorrealización individual"... "Digámoslo a la inversa, aspirar a la autodeterminación de los demás es el auténtico objetivo que está más allá de la autorrealización personal, la cual nunca está en detrimento de la autodeterminación de la persona" 194 . En esto, como en todo es fundamental avanzar en sintonía y unidos; no debemos caer en una nueva dominación, ni en la manipulación ni en la retórica: "Así, volviendo al problema que estamos tratando aquí, si la gente inicia la apertura de un nuevo espacio de autodeterminación tiene que esforzarse en no proceder de una forma retórica. Este es la vez un objetivo no siempre fácil de alcanzar y es, a la vez, un auténtico test de la autenticidad de nuestras intenciones" 195 . El hombre honrado pone la moral por encima de lo inmediato, pero no renuncia tampoco a lo que le corresponde aunque prefiera sufrir la injusticia que cometerla. El postmoderno respeta al otro y nunca lo utiliza: "Si alguien comete una injusticia con otro o le enga-

192. Ib., 184

193. Ib., 184

194. Ib., 189

195. Ib., 191-192 
ña, ha violado la autonomía de ese otro, ha rechazado el reconocimiento de las necesidades de ese otro y no ha sido capaz de cooperar con su semejante; abreviando, ha utilizado al otro como mero medio"196.

La postmodernidad aspira además a vivir experiencias más allá de lo inmediato y de la realidad social, a esas vivencias que hacen que la vida sea realmente vivir y tenga algún fundamento. Son momentos de gozo y realización sin los cuales la vida carecería de gracia y sería "una vida absolutamente desgraciada", es lo que Maslow llama "experiencias cumbre": "Por el hecho de surgir de la vida como totalidad y regresar a ella también como totalidad, una experiencia cumbre puede convertirse en inspiración para la persona, puede ser "cazada" aunque no perpetuada. Repitiendo, la actitud de la autodeterminación actúa como un tónico. Es debido a esta actitud que la experiencia cumbre puede aromatizar cualquier otra experiencia. Metafóricamente hablando: hace que la vida sepa bien. Y es cierto, la vida con la que estamos satisfechos sabe bien"197.

La ética y la política postmodernas exigen además invariablemente igualdad. La meritocracia no es un buen camino de justicia, pues, de hecho no hay igualdad de oportunidades. Por eso Rawls formula un "principio de diferencia según el cual una realización excelente se merece una remuneración más alta sólo si mejora directamente la situación del grupo humano más marginado"198. En este sentido el test del racismo es fundamental; así los jóvenes rechazan el liberalismo inmoral de los gobiernos. Como diría Daniel Cohn-Bendit: "La inexistencia de racismo entre los jóvenes franceses es, afirma, el cambio de mentalidad más importante"199. Los miembros de los estados ricos no deben desligarse de los demás seres humanos, de otro modo las diferencias de clase entre ciudadanos se agudizaría entre los distintos paises. Y lo deseable es que el mejor nivel de vida de libertad de unos pocos se contagie poco a poco y cree un nuevo futuro estructural: "Esta suavización del conflicto generacional no es más que una señal, dentro de muchas otras, de los cambios estructurales en los que están insertados los nuevos movimientos culturales"200. Las oleadas generacionales del 1946, 1968, 1986 han pluralizado lo vital, lo cultural y lo social. Mayo del 68 y la postmodernidad significan.el intento de renovación de la educación, de la familia, de la vida

196. Ib., 196

197. Ib., 196

198. Ib., 211. Sobre el principio de igualdad de oportunidades en la educación cfr. MARTIN IzQuiERdo, H., Contexto socio-ecológico de la socialización infantil, en los sociotipos urbanos de Valladolid, Centro nacional de Investigación y Documentación Educativa, Madrid 1986

199. Citado por BASSET, L., Dany, el Rojo, en El País, 29 de noviembre de 1986, internacional, 5

200. Feher, F., A., Heller, Políticas postmodernas 235 
cotidiana, de la vida amorosa, de la religión. No se consiguió todo, pero se alteró el "tejido social" de siempre. Y se creó la conciencia de que era posible rebelarse contra muchas cosas y que todos y cada uno podía hacer esta rebelión ${ }^{201}$. Se ha triunfado de la fosilización etnocéntrica y clasista. Y en cierto sentido "todo vale" cuando se busca lo mejor: "Para muchos, este ilimitado pluralismo (del "todo vale") es señal de conservadurismo: ¿no son cruciales los temas centrales que exigen rebelión? Y, sin embargo, la verdad es que el postmodernismo no es conservador, ni revolucionario ni progresista. No es una oleada de esperanza en aumento ni una resaca de profunda desesperación. Es un movimiento cultural que hace irrelevantes las distinciones de este tipo. Porque tanto si son conservadores, rebeldes, revolucionarios o progresistas, todos forman parte de ese movimiento. Esto es así, no porque el postmodernismo sea apolítico o antipolítico, sino porque no representa ningún tipo de política"202.

Hoy el trabajo ya no produce identidad y es más bien el tiempo libre el que proporciona la identidad social y cultural. Existe una gran diversificación de ofertas, a la carta, en las que asimilamos los estilos de todo el mundo, según las preferencias, siempre que haya medios de satisfacer esas preferencias $^{203}$. A la vez nos encontramos con una generalización del estilo deportivo y juvenil. Todo mundo quiere ser joven o al menos no tener conflictos con los jóvenes e incluso se les imita para evitar la competencia: "Cuanto más fuerte sea la identificación con la función realizada, más grande es para la persona la tentación de convertirse en un aburrido autocomplaciente o en un arrogante burócrata. El que realiza la función se siente inevitablemente atraído a observar a los jóvenes porque ellos son la competencia"204. Hoy ni la revolución ni la continuidad son inevitables como parecía en otros tiempos. A lo más se puede aspirar a una libertad y a una felicidad progresivas, por tanto una "política de los mortales", no elitista, como pensaba Jefferson. No se puede prometer más. En ese sentido veremos que no hay final de la historia porque aún hay mucho que arreglar, o de lo contrario nos encontraremos con la frustración, no hay paraíso materialista, ni idealista: "Prometía un paraíso terrenal que invariablemente resulta ser un "jardín de estúpidos, un período de profunda desilusión y cinismo. Creer en el "final de la historia" hace exageradas nuestras demandas, irresponsables nuestras promesas, intemperados nuestros gestos y fantásticas nuestras convicciones. El resulta-

201. Ib., 239

202. Ib., $239-240$

203. Ib., 243

204. Ib., 245 
do es un tipo de política que promete redentores y nos entrega a los inquisidores"205. A lo mejor no ha llegado el fin de la cultura occidental, a lo mejor "hay que detener a los enterradores", a lo mejor es posible una modernidad sin violencia, la postmodernidad, en que occidente ha abandonado "la guerra, las conquistas", y vamos a mundo nuevo que ya no es puro "museo", sino un sueño de la nueva realidad: "Lo que promete un nuevo marco europeo es el surgimiento de la virtud cívica, el gusto, la educación de los sentidos, la urbanidad, civilidad, la alegría, la nobleza, unas formas de vida nacidas con dignidad, sensibilidad por la naturaleza, el drama, la pintura, la piedad, la cultura erótica y muchas cosas más. Además, lo que aquí se sostiene sobre una futura cultura europea puede sostenerse sobre cualquier marco cultural posible" 206 .

5.3.- Hoy estamos ante el alba de los sueños en los paises del Este. El momento de la renovación y de la transparencia general ha comenzado, aunque necesitará un gran esfuerzo. "En la actualidad, nuestra principal tarea consiste en elevar espiritualmente al individuo, respetando su mundo interior y proporcionándole fuerza moral. Pretendemos que todo el potencial intelectual de la sociedad y todas las posibilidades de la cultura se dedique a moldear personas socialmente activas, espiritualmente ricas, justas y concienzudas. Todo individuo debe saber y sentir que su contribución es necesaria, que su dignidad es respetada, que se le trata con confianza y respeto. Cuando una persona ve todo esto, es capaz de hacer muchas cosas"207. Muchos se sentirán incómodos, les parecerá que se les interrumpe su vida habitual, especialmente los "gorrones" que viven del cuento, al tener todo sin hacer nada. Hay personas que se aprovechan del sistema, del grupo en anonimato, con todos los derechos sin ningún deber. "Trabajan mal, se desentienden de sus responsabilidades y beben en exceso. Hay un buen número de gente que ha adaptado las leyes y las prácticas existentes a sus propios intereses egoístas. Es muy poco lo que ofrecen a la sociedad, pero se las arreglan para sacar de ella todo lo posible e incluso lo que parece imposible. Viven de ingresos no merecidos"208. Es necesario darse cuenta de si hemos caído en el filisteísmo, en el consumismo o en la retórica de la hipocresía. "Todos debemos volvernos hacia nuestro interior para determinar si estamos viviendo y actuando según nuestra conciencia... Si aprendemos a

205. Ib., 282

206. Ib., 299

207. Gorvachev, M., Perestroika, Circulo de Lectores, Barcelona 1988, 32

208. Ib., 33 
trabajar mejor, a ser más honrados y decentes, entonces podremos crear un sistema de vida verdaderamente socialista"209.

Es necesario una profunda democratización de la vida social de modo que la renovación sea asumida por todas las personas, por todo el pueblo personalmente. Esa es también la mejor garantía de la profundidad del cambio, de un mejor conocimiento de los problemas y de la asimilación de los ideales del nuevo mundo con sencillez y realismo, sin arrogancia ni retórica. "En principio, empero, puedo decir que el resultado final de la perestroika está bastante claro para nosotros. Se trata de una renovación a fondo de todos los aspectos de la vida soviética; de dar al socialismo las formas progresistas de organización social; de acentuar al máximo el carácter humanista de nuestro sistema social en sus facetas más esenciales, la económica, la social, la política y la moral"'110. Esta renovación no se hará de la noche a la mañana como por una revelación o una iluminación repentina ni de una forma ajena al sentido profundo de la sociedad, se trata más bien de "comprender la necesidad objetiva de renovación y de aceleración". En el caso del mundo socialista sería una profundización del socialismo en sus aspectos esenciales, según la teoría revolucionaria; pero no se trata de ponerlo todo patas arriba para luego corregir los errores. "Más socialismo significa un ritmo más dinámico, una conducta más creativa, mayor organización, ley y orden, una metodología más científica y más iniciativa en la dirección económica más eficacia en la administración y una vida materialmente más rica para el pueblo"211.

Es necesario no perderse en discusiones al comienzo, hay que ponerse en camino, salir del atolladero briosamente aunque con calma, a pesar de la resistencia a los cambios, a pesar de la irresponsabilidad de algunos, de la indiferencia, la inacción y la incompetencia de otros. "Sencillamente, no tenemos derecho a descansar ni un solo día. Por el contrario, día tras día debemos aumentar nuestros esfuerzos y conferirles mayor intensidad. Hemos de ser capaces de soportar esta presión, que los cosmonautas denominan "gran sobrecarga", de las fases iniciales de la reestructuración"212. No se trata simplemente de lavar la cara de nuestra sociedad o de poner unos cuantos parches, sino de una renovación de la sociedad y de una recuperación de las personas, completa. Se trata de una nueva calidad de vida con una mayor trasparencia y menos egoísmo; a pesar de la resistencia del conservadurismo debemos ir hacia lo nuevo aunque el cambio de lo ya habitual

209. Ib., 34

210. Ib., $39-40$

211. Ib., 41

212. Ib., 60 
de lugar a protestas, pues se trata de alcanzar todas las esferas de la vida. Porque, en definitiva. "Debemos volvernos mejores de lo que somos y estar dispuestos a ayudar aquellos que no pueden mejorar por sí solos. Lo principal es ser concienzudos"'213. Así pues, la perestroika, la renovación, es un compromiso ético y social general que a nadie excluye, pues se dirije a toda la sociedad. Para ello ha sido necesario emprender decididamente la tarea y "eliminar el mecanismo de frenado". En este momento, todas y cada una de las personas deben asumir su propia responsabilidad. Hay que trabajar todos y no esperar que las cosas lleguen y se hagan desde arriba; no se pueden esperar milagros: "Algunas personas parecen albergar la esperanza de que todo vaya a cambiar de pronto y por iniciativa propia, sin ningún esfuerzo especial por su parte. Muchos piensan que basta con que hayan surgido nuevos dirigentes para que todo cambie y se arregle. Pero es un error creer que a partir de ahora todo va a ser un fácil paseo cuesta abajo"214.

Mucha gente ha perdido la creatividad y la iniciativa, es necesario recuperarla; todo mundo es necesario, pero no basta estar pegado al "reglamento o hipnotizados por el dogma social", se necesita una gran inyección de creatividad, pues la pasividad nos ha avasallado: "El problema es que la gente perdió la costumbre de pensar por su cuenta y de actuar de forma independiente y responsable, y no es problema pequeño"215. Como consecuencia, mucha gente ya no se tomaba en serio las reuniones ni los grupos; se dice a todo que sí pero luego no se hace nada, es una "farsa". es preciso curarse "de la indiferencia" para creer realmente en la "justicia y en la democracia". $\mathrm{Y}$ eso lo necesitan tanto las jerarquías como también el pueblo. Es necesario "transformarnos nosotros mismos" para salir realmente adelante con futuro y no quedar petrificados. Pues "Mucha gente -me refiero a las generaciones nacidas en los años treinta, cuarenta y cincuenta- se ha quedado osificada. $Y$ no me da miedo utilizar esta palabra"216. No se trata de caer en una anarquía general. Hay que ayudar la democratización y la trasparencia con decisión. Pero tampoco se trata de mera retórica como tantas veces sucede: "Hay personas que en apariencia están a favor de todas las innovaciones, pero cuando llega el momento de la acción, condicionan el desarrollo de la democracia, la crítica y la glasnost con toda suerte de limitaciones y reservas... necesitamos la glasnost como el aire que respiramos"217. 
La discusión y la crítica son imprescindibles para que aparezca la verdad y la razón que cada uno lleva. La crítica es como una medicina, es "amarga" pero necesaria "uno tuerce la cara, pero se la traga" y hace bien. No se puede creer que uno tiene toda la razón. Pero lo peor sería una inteligencia y una sociedad pasiva, "sumida en la indiferencia y el cinismo"218. Hay que discutir las cosas todos juntos sin "la influencia de la inercia" y caminar hacia adelante. Además hay que reconducir las cosas hacia las personas concretas sin permitir la impostura de los reinos de taifas. Es necesario conseguir que las personas se hagan realmente cargo de las cosas y trabajar para que no se aislen en su castillo de hierro o de cristal. De ser así se caerá fácilmente en el alcoholismo que no se puede superar sin actividades culturales comunitarias, el amor a la vida sana y la democratización de la vida social de modo que todos participen. Además es absolutamente necesario que la sociedad mejore en sus "valores morales": "La gente espera un ejemplo moral, y lo espera en particular de sus superiores. Abundan los ejemplos a este respecto. Allí donde hay un buen director, se impone el éxito. Él se preocupa de todos, y a todos les gusta hablar con él. No necesita alzar la voz para dar órdenes. Puede tener un aspecto corriente, pero lo ve todo y sabe explicarlo todo"219. Hay que abandonar las formas rutinarias, las campañas grandilocuentes, los falsos esplendores, las consignas abstractas y burocráticas que ahogan "las fuentes vitales" de las iniciativas del pueblo. Deberíamos hablar menos de renovación y hacer más. "Lo que se necesita es más orden, más conciencia, y es bueno que la gente lo comprenda. Es más, la gente lo acepta en su mente y en su corazón, y esto es importante"220. Los jóvenes y las mujeres deben participar realmente en el proceso social y político, no basta decirles buenas palabras o darles un poco de ánimo y diversiones. Es necesario dar a las personas mejor capacitadas, sin exclusivismos ni cerrazones, un espacio apropiado para su participación creativa en la perestroika. Cada período tiene sus hombres con la competencia y profesionalidad que exige la nueva sociedad. Es necesario además nivel humano y moral: "El Comité Central exige que las personas elegidas para altos cargos sean modestas, decentes, honradas y a prueba de toda clase de lisonjas y adulaciones. En el Partido, no puede haber nadie que esté al margen de la crítica, ni nadie que no tenga el derecho a criticar"221.

Es preciso devolver a la gente la fe en sus propias posibilidades. $Y$ hacer las cosas con la máxima responsabilidad moral y social. Nada se conseguirá

218. Ib., 100

219. Ib., $128-129$

220. Ib., $129-130$

221. Ib., 153 
con la violencia, o las coacciones: "Todo lo que se intente como un diktat militar, así como bajo presión moral, política y económica, está hoy totalmente desfasado"222. Además todos esos métodos obstaculizan la paz que es absolutamente necesaria para llevar adelante la renovación. Mirando hacia afuera nadie puede eliminar ni el capitalismo ni el socialismo. En esto hay que ser realistas. Nadie puede ganar la guerra, ni la carrera de armamentos, ni ninguna batalla. En esto hay que ser muy sinceros y no engañarse. Por otra parte la gente está cansada de la "tensión y la confrontación", hay que respetar las convicciones así como "su modalidad de existencia". "Desde el aspecto de una política amplia y a largo plazo, nadie será capaz de subordinar a otros. Por esta razón, sólo queda una cosa, que son las relaciones de igualdad. Todos debemos comprenderlo"223. Las naciones del mundo están sujetas en la misma cuerda: pueden triunfar juntas o hundirse juntos "en el abismo". "La humanidad merece un destino mejor que el de ser un rehén del terror nuclear y la desesperación"224. Hoy las relaciones internacionales deben basarse también en la ética y las "normas morales"; esto es algo vital actualmente. La guerra ya no soluciona nada. Cada cual puede y debe poder elegir, capitalismo o socialismo, es su propio "derecho soberano". Cada uno tiene que aprender por sí mismo: "No pretendemos enseñar a los demás. Después de haber oído de otros instrucciones interminables, hemos llegado a la conclusión de que éste es un pasatiempo inútil. Es, sobre todo, la propia vida la que enseña a la gente a pensar de nuevo"225.

La preocupación por la humanidad es lo que debe unir a los pueblos. Es necesario más valor para la paz que para la guerra. La competencia debe ser leal y nadie debe tratar de abolir al otro. Hay que estimular los deseos de buena voluntad, de paz, de supervivencia de la humanidad. En todo esto juegan un papel decisivo los valores humanos. "La espina dorsal de la nueva manera de pensar es el reconocimiento de la prioridad de los valores humanos, o, para ser más precisos, la supervivencia de la humanidad... Cabría argumentar que en todas las épocas los filósofos y los teólogos han tratado las ideas de los valores humanos "eternos". Es cierto, pero entonces éstas eran "especulaciones escolásticas" destinadas a no pasar de un sueño utópico. Cuando finaliza este siglo dramático, la humanidad debe reconocer la necesidad vital de los valores humanos, así como su prioridad"226. Quien no se preocupe por el futuro de todos, de la humanidad, ni es moral ni merece- 
ría, de por sí, respeto alguno. Se necesita sacar a la humanidad de las amenazas del "holocausto nuclear". Hay que olvidar las artimañas y las maniobras tácticas. "Nadie puede ya engañar a los demás. Es lo que repito una y otra vez a aquellas personas de Occidente que hablan conmigo... Lo que se requiere hoy de los dirigentes es una evaluación correcta de las realidades, una mente lúcida y un sentido cada vez mayor de la responsabilidad"227. El "diálogo" es hoy fundamental e inexcusable, todos podemos enriquecernos con las diversas tradiciones culturales. El autor de La perestroika no pretende "convertir a nadie al marxismo". Además: 'El proletariado victorioso no puede imponer a ninguna otra nación su propia idea de una vida feliz, sin perjudicar con ello su propia victoria'. Esta declaración de Marx es una definición precisa de nuestra actitud frente a toda clase de "exportaciones de revolución"228. Los problemas son aún muchos, pero se ha preparado ya el terreno "Y creemos que el mundo cambiará para mejorar. Ya está cambiando"229.

Hay que elevar la sociedad a su nivel cualitativamente nuevo. El mundo cambiará si cada cual se preocupa por sus problemas, por los de sus amigos, y respeta a los otros. En todo el proceso es más importante la colaboración crítica de todos y las iniciativas de unidad que "los fuertes aplausos" a lo ya hecho. Cada pueblo debe tomar sus decisiones; todos debemos intercambiar nuestras experiencias e implicarse en la tarea de la renovación: "En la toma de decisiones, se basa más en el principio del consenso, más que en el voto mayoritario"230. La renovación necesita de la verdad, analizar realmente las cosas, con voluntad de objetividad y de acertar y eso es realmente muy duro. Esto es un cambio revolucionario que requiere enorme esfuerzo. "Lo importante es que estemos convencidos de la importancia de la cooperación y de la necesidad de ampliarla"231. Los intereses particulares no deben usarse para generar conflictos, ni entre los hombres ni entre las naciones. La perestroika aboga por un "hogar común europeo" que recoja lo mejor de la tradición frente a una cultura superficial de los bajos sentimientos y de "la violencia", lo cual no significa exclusión de alguien: "Nuestra idea de "hogar común europeo" no significa un intento de cerrar las puertas a nadie"... (pero también indica el hecho de que) "no puede más que asombrarnos que una cultura europea, profunda, inteligente e intrínsecamente humana se bata

227. Ib., 199

228. Ib., $189-190$

229. Ib., 201

230. Ib., 211

231. Ib., 213 
en retirada ante la diversión primitiva de la violencia y la pornografía, y la riada de sentimientos vergonzosos e ideas de baja catadura"232.

Hay que conseguir una mejor comunicación entre todos, también entre todos los paises para evitar las patrañas de las ideologías. Hay que evitar la arrogancia del poder, el cinismo del militarismo de las naciones más desarrolladas. No hay que ver a los otros como "la encarnación del diablo" y a los nuestros como "la bondad absoluta". Bajo esos esquemas las relaciones humanas no pueden ser normales. Nadie puede considerarse la inmaculada concepción. Occidente también tiene sus sombras, como tiene también sus luces, los humanos somos paradójicos que juntan fácilmente: "Interminables alegatos por la libertad del individuo, intentos por imponer su estilo de vida a otros, propaganda en gran escala del culto a la fuerza y a la violencia" 233 . Dejando los intereses egoístas es necesario apoyar a los paises en desarrollo, enfrentándose al problema de la deuda externa, eliminar las armas, utilizar la tecnología para bien de todos, erradicar el racismo, reconstruir la familia y no penalizar a nadie sin la ONU. En estos momentos difíciles de la historia, el realismo es absolutamente necesario, tanto "como el aire" que respiramos. No podemos dejarnos llevar de las ideologías. "Existe la realidad y debe respetarse. De otra forma la política se convertiría en una improvisación, en desplazamientos de un extremo al otro, en lo impredecible"234. Hay que pasar del miedo a la confianza, hay muchas personas dispuestas a ello. La perestroika, la renovación es buena para todos, todos tenemos mucho que aprender para solucionar los graves problemas ecológicos, sanitarios, económicos, de nuestro mundo. "Todos somos estudiantes, y nuestro maestro es la vida y el tiempo... Queremos que la libertad reine soberana en el próximo siglo en todos los rincones del mundo. Queremos la competencia pacífica entre los distintos sistemas sociales para su desarrollo sin estorbos, para alentar la colaboración mutuamente provechosa por encima de la competencia en una carrera armamentista. Queremos que la gente de todos los paises goce de prosperidad, bienestar y felicidad. El camino para ello se basa en la consecución de un mundo desnuclearizado y sin violencia. Nosotros nos hemos puesto en camino y hacemos un llamamiento a los demás paises y naciones para que nos acompañen"235. Todos somos responsables del futuro, de la suerte y de la historia de la humanidad y hay que aunar esfuerzos para

232. Ib., 261

233. Ib., 269

234. Ib., 314

235. Ib., 317 
no obstaculizar los planes de Dios, la obra de Dios. "Todos somos responsables hoy del futuro del mundo"236.

\section{6.- El famoso fin de la historia (en teoría)}

Francis Fukuyama, funcionario de la oficina de planificación a largo plazo del Departamento de Estado de los Estados Unidos ha provocado una discusión periodística internacional a raíz de la publicación de un artículo titulado: “¿El fin de la historia?" en la revista conservadora americana "The National Interest", n' 16 del verano de 1989. Ríos de tinta se han vertido en la polémica y como dice el mismo Fukuyama veo que "he logrado un consenso universal único, pero no sobre la situación actual del liberalismo, sino sobre el hecho de que estoy equivocado y que en realidad la historia no ha terminado"237. Análisis y más análisis se han sucedido acerca del famoso artículo de forma inesperada. De modo que: "Lo más curioso del fenómeno Fukuyama no está en Fukuyama, sino en el revuelo que ha provocado: más parece un fenómeno social que un fenómeno intelectual"238. Según este autor español, director del Centro de Estudios de Política Exterior: "En la práctica tan sólo hay una refutación posible de la tesis de Fukuyama. De. puro evidente ha pasado inadvertida. Más de un comentarista ha señalado que hacer extensivo a la eternidad y al orbe entero lo que ocurre hic et nunc es desvarío. Pero nadie ha sacado la consecuencia lógica. Yo propongo el siguiente silogismo: para creer que una situación local y temporal es global y perenne hay que ser un prodigioso ignorante y un aldeano catetísimo. Es así que Fukuyama no es ni lo uno ni lo otro, ergo no se cree lo que nos cuenta. Es así también que no gana nada engañándonos, más que el placer de tomarnos el pelo, luego toda su teoría es una broma"239. Pero esto no lo dice sola-

236. Ib., 258: Gorbachov refiere lo siguiente: "No me parece que les desvele un gran secreto si les relato algo que me explicó el presidente del Senato italiano Amintore Fanfani. En una ocasión habló de la difícil situación internacional con Eduardo De Filippo, el famoso dirẹctor italiano. ‘¿Y qué podemos hacer nosotros?' preguntó De Filippo. 'Confiar en Dios'; contestó Fanfani. 'Entonces no permitamos que la gente obstaculice la obra de Dios', replicó De Filippo.

Esta noción de que todos somos responsables del futuro del mundo es de gran importancia y valor hoy día. Y debería dárseles crédito a algunos políticos de la Europa Occidental, al reconocer que todos los europeos deben aunar sus fuerzas y conservar las bases eștablecidas en Reykiavik".

237. FukUyama, F., Respuesta a mis críticos. El fin de la historia no significa el fin de los acontecimientos del mundo, El País, Temas de nuestra época, $n^{\circ} 11$ (12.12.1989) 3

238. Mora-Figueroa, S. de, (Marqués de Tamarón), El acabose. Nueva Revista de Política, cultura y arte, 1 (febrero 1990) 41

239. Ib., 45 
mente un plumífero ibérico, más o menos sesudo. El mismo creador de The National Interest, Irvin Kristol, afirma con una sonrisa irónica: "Yo no me creo ni una palabra del asunto"240. Por lo que no dudaría, seguramente, el mismo Kristol en firmar la conclusión de nuestro escritor que no tiene desperdicio: "No, no debe de haber llegado el acabose histórico. Clio, musa de la Historia nos mandará un día de estos un mensaje como el telegrama de Mark Twain a la Associated Press: "La noticia de mi muerte era una exageración"" 241 . Según nuestro autor hay que leer a Aristóteles sobre la caducidad de los regímenes, en vez de a Hegel; además Hegel era un loco según Schopenhauer y el que está dispuesto a creer a Hegel es capaz de creer cualquier cosa (David Stove); finalmente el ensayo de Fukuyama sería "teológico" o "marxismo vuelto al revés"242. De mismo modo James Atlas en el escrito aquí citado resume las más variadas acusaciones contra Fukuyama, sin excluir la ironía del aburrimiento. Burton Yale Pines le acusa de ser el nuevo Mister X. Este era George Kennan que el 1947 trabajaba en el Departamento de Asuntos Exteriores y escribió de forma anónima sobre el gran peligro ruso y sus artimañas que justificó la política de firmeza y vigilancia de la postguerra o guerra fría. Ahora Fukuyama sería un alibi para la situación inesperadamente provocada por las revolucionarias posiciones políticas de Gorbachov y la perestroika ${ }^{243}$. Pero Fukuyama no se ha quedado congelado y ha contestado a sus críticos: En primer lugar, la idea del fin de la historia es un concepto estrictamente hegeliano que cualquiera puede aceptar e incluso Marx lo supone aunque se oponga prácticamente a él. Además Fukuyama sabe que siempre hay un cierto historicismo, aunque no todo puede ser historicismo. En segundo lugar, Fukuyama admite que no resaltó bastante las dificultades para la realización del fin de la historia, sabe que el proceso no será fácil. Sin embargo quiere insistir en lo siguiente: "Pero hemos de reconocer que en el mundo está en marcha, una revolución importante, y que en esa revolución cuentan las ideas"244. En esta cuestión tiene bastante razón Fukuyama. Se disculpa sobre los malentendidos del Tercer mundo y contraataca en otros aspectos. Por ejemplo, admite que puede haber retrocesos, como los sucesos de Pekín de 1989 y otros que pudiera haber en Rusia más serios, además de las cuestiones nacionalistas, que tienen su importancia. Pero no como para pensar que cuestiones locales puedan provocar hoy

240. Citado por AtLas, J., What is Fukuyama saying?, The New York Times Magazine (22.10.1989) 42

241. Mora-Figueroa, S., El acabose, 45

242. Ib., 42

243. AtLAS., What is Fukuyama saying?, 55

244. Fukuyama, F., Respuesta a mis críticos, 4 
un conflicto internacional, si bien conviene advertir que actualmente nunca se sabe muy bien qué son cuestiones locales y qué sea cuestiones internacionales. El nacionalismo puede igualmente ser virulento como dice Allan Bloom, pero también es cierto que hoy hasta el terrorismo en nombre del nacionalismo, se queda reducido, con frecuencia, a estatua de sal muchas veces.

Por último, Fukuyama responde a los que citan la última parte de su escrito sobre el aburrimiento en una sociedad liberal dando cuenta de que con frecuencia en esta sociedad al ciudadano se le invita de un modo y otro a la rutina y a la irresponsabilidad cuando se insiste tanto en la igualdad y en el consenso. En efecto: "El hecho de no tratar la cuestión del contenido de una buena vida, es realmente el motivo de que el liberalismo funcione, pero también significa que el vacío que constituye nuestra libertad se puede llenar de cualquier cosa: indolencia y autocomplacencia, moderación y valor, deseos de riqueza y preocupación por el beneficio comercial, amor por la sencillez y búsqueda de la belleza, trivialidad y espiritualidad"245. Del mismo modo el exceso de seguridad puede provocar búsqueda nefasta de riesgo. Finalmente reconoce Fukuyama, en parte, las críticas de Bloom y de Hassner, y sabe que es posible que todo se venga abajo. Como diría Régis Debray: "Todo el mundo en política pretende ser realista, pero lo esencial es saber qué es lo real, o, cuando menos, más real que lo que resta"246.

El tema suscitado por Fukuyama no es estrictamente nuevo, sí son nuevas las dimensiones que ha cobrado el asunto, en absoluto esperadas. Pero, por ejemplo, H.G. Gadamer, haciendo balance de su vida filosófica, en un articulo reciente sobre "el fin del arte" se expresaba de este modo:"Hegel, ese valiente suabo, afirmó comprender en su propia mente la perfección de toda la historia del pensamiento y el alma de Occidente; más aún, de la historia de la humanidad en general. Abrigaba la convicción de que la historia tocaba en cierto sentido a su fin, ya que había dejado de ser posible toda duda y discusión sobre el principio por el cual discurre la trayectoria de la historia mundial: el camino de la libertad para todos era lo que constituía la razón de la historia. Esta es la conocida teoría de Hegel, de la que podemos decir que dió a conocer con juicio certero un principio que alcanzó su victoria final en la Revolución Francesa pero que en el fondo surgió en el mundo con el cristianismo. Es indiscutible que todo ser humano debe ser libre y que no deben existir esclavos ni esclavización de ninguna clase. La historia consiste en el

245. Ib., 6

246. Debray, R., La sabiduría del rebelde. Una soberbia que ocultaba su clarividencia sobre el futuro. El País. Temas de nuestra época (16.6.1990) 10 
intento de realizar este ideal, así lo enseñó Hegel y por eso sigue adelante la historia mundial en la época de las revoluciones que luchan por esta realización: como la lucha de dominio contra dominio y por la liberación del dominio... una lucha cuyo fin aún no puede preveerse"247. Como se ve, Gadamer difiere claramente de Fukuyama en cuanto al pretendido fin de la historia. Además ve cómo esa realización es un ideal que aún no ha podido actualizarse del todo ni plenamente. Se va haciendo paso a paso. Y no se sabe cuándo llegará al fin y su cumplimiento. Muchas veces se ha proclamado el fin de tal o cual cosa, pero de lo dicho apenas ha habido nada. Lo dice muy bien Gadamer: "No es, sin embargo, sólo el fin de la historia el que aparece ante nuestra experiencia real bajo una luz dudosa. Lo mismo sucede con el fin de la metafísica, que a principios del siglo XIX fue proclamado por primera vez a través de Auguste Comte bajo el lema del "positivismo", la philosophie positive: "La era de la metafísica ha terminado. Hemos entrado en la era de la ciencia". Esto se dijo y aseguró una y otra vez"248. Pero nada se ha confirmado de forma definitiva.

Otros autores han incidido en este problema del fin de la historia de distintas formas. Así T.W. Adorno cree que Hegel, a veces, piensa en la historia como cumplimiento de la providencia, no se da cuenta de la violencia en la historia, glorifica la fuerza de la dominación social como historia auténtica. Los mismos increyentes, afirma Adorno, han divinizado la historia: "La divinización de la historia era de lo que se trataba incluso en los hegelianos ateos Marx y Engels"249. Así se introduce la dominación como naturaleza de la trama histórica. La eternidad de la historia sería la eternidad de la destrucción. Por el contrario la historia es caducidad, contingencia y finitud. En este sentido se acercaría bien a la interpretación de Fukuyama de que la historia debe ser historia de la libertad humana actual, no historia del Absoluto dominador. G. Vattimo volverá sobre este asunto. Fukuyama debe tener mucha precaución para no volver a las andadas proclamando un futuro absoluto universal. Lo propio de la historia es la caducidad. Lo sabía muy bien Adorno: "De todos modos, el elemento en que naturaleza e historia llegan a ser mutuamente conmensurables es el de la caducidad. Así lo ha comprendido a fondo Benjamín en sus Orígenes de la tragedia en Alemania. Según él los poetas del barroco presienten la naturaleza "como eterna caducidad, en

247. Gadamer, H.G., ¿El fin del arte? en La herencia de Europa. Península, Barcelona 1990, 65-66. Este artículo de Gadamer se publicó originalmente en alemán en el año 1985. El subrayado es nuestro.

248. Ib., 66

249. Adorno, T.W., Dialéctica Negativa, 319 
la que sólo la mirada satúrnica de aquella generación reconoció la historia"... El signo de caducidad escribe en el rostro de la naturaleza: "historia". El drama pone en escena la fisionomía alegórica de historia-naturaleza, presente en la realidad actual como "ruina". Así se realiza la transmutación de la metafísica en historia. La metafísica queda secularizada a la categoría secular por excelencia, la ruina. La filosofía interpreta este jeroglífico, el menetekel siempre renovado, a partir de lo mínimo, de los fragmentos que arranca el desmoronamiento y que son los portadores de significaciones objetivas. Sólo la decadencia permite aún mantener el recuerdo de la transcendencia; la eternidad no aparece como tal, sino quebrada a través de lo más perecedero que hay. Allí donde la metafísica hegeliana equipara transfigurativamente la totalidad de la caducidad de todo lo finito con la vida del Absoluto, levanta la vista un poquito por encima del hechizo mítico que absorbió y potenció" 250 . Toda historia verdadera es historia de la caducidad. Sólo así se conjura el retorno de los brujos y de los falsos mesías, cuando la historia no da realmente la espalda a ningún dolor humano. En otro caso la historia será una vez más el reconocimiento del héroe de la fuerza y de las fuerzas armadas. En este sentido reclamaba P. Dollé: "lo que pido al pensamiento es que me haga creer que hay otro lugar distinto de la correlación de fuerzas"251. La glorificación de la fuerza es muy propio de la sociedad productiva, pero una vez más lo que encanta es lo que mata.

Para F. Feher y A. Heller la idea de posthistoria pude indicar el fin de la hegemonía occidental, o también la erosión de las diversas y ricas tradiciones culturales reducidas a cenizas en una cultura básica "vernácula" sin ninguna capacidad creativa frente a la laminadora del sistema: "La posthistoria puede ser un intento de recuperar todas las historias humanas que Europa, esa madre posesiva, nos ha impedido. Pero puede señalar también la erosión de distintas tradiciones culturales unificadas. El derrumbamiento de estas podría tener un devastador impacto en el sistema de educación que se basa firmemente en lo vernáculo de la tradición"252. De este modo se cerraría el paso a los marginados y a los oprimidos de la tierra que habrían de perder toda esperanza, mientras los mejor situados se encierran en un bienestar ostentoso y cínico pero carente igualmente de esperanza. Se llega así al funeral del mito del siglo XIX: la emancipación occidental; su inspiración se ha agotado. "Tal vez haya llegado el momento del funeral"... "Europa, la poderosa, la líder del mundo, ya no existe, Europa, la fuente de inspiración de

250. Ib., 359

251. Aubral, F., Delcourt, Contra la Nueva Filosofía. Trad. castellana de J. Mejía. México 1978, 11 
todas las culturas superiores se ha agotado. Descanse en paz"253. Pero hay otra historia de Europa que surge ahora al integrar también a la Unión Soviética y que promete un nuevo futuro de ciudadanía, dignidad, piedad y libertad. Entonces hay que detener a los enterradores, no hay cadáver que enterrar. La libertad es posible. No hay "desesperación", a pesar del final de las políticas de los redentores y precisamente por eso. Se suaviza y se detiene la confrontación y la razón de la fuerza. Se pide otra sociedad. No se puede instrumentalizar a la gente. Todos somos mortales. Sólo hay un acto político que transcienda hipotéticamente nuestra mortalidad, y éste es la creación de instituciones "libres y perdurables"254. Quizá todo sea un sueño. Tal vez no. No sabemos: "A un sueño no puede escribírsele un prólogo; un sueño es demasiado subjetivo para convertirse en un género público. Pero los que comparten el "sueño europeo" en verdad no pueden escribir un epílogo. $\mathrm{Su}$ sueño puede hacerse aún realidad" 255 . La historia verdadera comienza ahora ya. Pero no hay una historia ni un progreso inmóviles, en sí.

Este proceso sólo es posible con un empleo responsable de la sabiduría y la ciencia de la humanidad. Es necesario abandonar el "afán de imposición". La historia tiene que dejar de ser el "juego de las fuerzas" que nos rodean. Hay un peligro de uniformación por la democracia. Pero, peor aún, la sociedad tradicional ha sido violenta y guerrera, es necesario pasar a una pacificación social dejando de lado los códigos de honor y de venganza con una nueva ética de la generosidad o nunca saldremos del círculo vicioso de la dominación y la crueldad. La fuerza destruye la vida y la intimidad. "El honor y la venganza han perdurado bajo el Estado, al igual que la crueldad de las costumbres"256. Sólo con una nueva sensibilidad es posible un nuevo comienzo de la lucha contra el sufrimiento y la humillación del hombre, un nuevo fin de la historia por el sometimiento del Leviatán de las fuerzas irracionales.

El débil subrayado y la insuficiente insistencia en estas últimas realida'des son las que han irritado gravemente a los contradictores de Fukuyama. Así N. Chomsky le recuerda el papel actual de su país en muchas partes del mundo, desde Oriente asiático (Vietnam) pasando por América Latina y sin olvidar el mundo Arabe donde pretende imponer la justicia de Goliat257.

252. FeHER, F., A. Heller, Políticas postmodernas, 16

253. Ib., 295

254. Ib., 283

255. Ib., 299

256. Lipovetsky, G., La era del vacío. Trad. castellana de Anagrama, Barcelona 1987, $2^{\mathrm{a}}$, 
Además el actual sistema produce una jerarquización intolerable para la libertad. Por otra parte Fukuyama puede dar la impresión de padecer la enfermedad histórica de la escisión entre la teoría y la práctica ${ }^{258}$. El mundo occidental liberal no necesita proclamar apresuradamente sus éxitos. Debe meditar, como buen administrador, en los costos y, si es capaz, recordar las fuertes y sangrantes heridas en las espaldas sobre las que los buenos futuros se construyeron. Otra cosa sería proceder como hombres carentes de memoria. Dos autores se han ocupado de recordarle a Fukuyama que la sociedad liberal busca su provecho, su propiedad, con exclusión de los demás, compra el trabajo con frecuencia injustamente por lo cual muchas familias carecen de recursos y se niega así realmente la democracia económica. Eso sin entrar en muchos detalles y olvidando los millones de esclavos del pasado, el racismo y la destrucción de los pueblos jóvenes y subdesarrollados en el presente por la explotación permanente. En el mismo USA la mitad de los niños menores de 6 años viven en la pobreza con 30 millones de adultos la mayoría de ellos mujeres. Allí mismo 3 millones no tienen casa, 37 no disfrutan de seguridad social y 20 millones padecen hambre algunos días al mes ${ }^{259}$. Fukuyama no necesita ir tan de prisa a proclamar los éxitos del liberalismo occidental. Necesita meditar, y valorar un poco mejor las cosas, aunque haya mejorado la situación.

Es urgente revisar el escándalo del sistema monetario y del comercio (por no llamarle rapiña) internacional260. No hay que olvidarse del materialismo de Occidente cuando cae el materialismo histórico en el Este, ni pasar por alto el deseo humano auténtico de igualdad cuando el igualitarismo decae, ni dar de lado al sentido social a base de aprovechar la disolución del colectivismo para incrementar el individualismo y los propios privilegios 261 a costa de lo que sea. Por otra parte la moralidad y la ética capitalista no es superior a la del sistema marxista si bien ésta también ha demostrado en

258 Vattimo, G., Las aventuras de la diferencia. Península, Barcelona 1986, 34-35: "Si la enfermedad histórica se caracteriza fundamentalmente por la escisión de teoría y praxis, por lo cual no hay adecuación entre hacer y saber, y la acción histórica está condenada a ser inconsciente o a no ser acción, la ontología hermenéutica no representa su auténtica superación, en la medida en que olvida precisamente el problema de la unidad entre teoría y práxis como problema".

259 Surlis, P., P., JOYCE, Capitalism need not rush to claim victory. National Catholic Reporter, 3 (11.1989) 12

260. Drinan, R., Capitalism in which the rich filch from poor. National Catholic Reporter 1 (9.1989) 20

261. BlaCKBuRn, Th. E., Capitalism in which the rich might pitch in? National Catholic Reporter, 1 (9.1989) 20 
buena parte su mentira. También en Occidente hay profesionales universitarios que se aprovechan de la gente prometiendo larga salud o acomodando los programas universitarios a sus varios intereses; se persigue el propio provecho sin moral alguna de modo que la veracidad y el sentido de la responsabilidad están enormemente disminuidos 262 .

Por otra parte hay que darse cuenta de que la cuestión entre el liberalismo auténtico y el socialismo democrático no está resuelta en modo alguno. Es más, podemos llegar a "un aburrimiento", del que habla al final Fukuyama y este será más o menos injusto: "El Schumpeter pesimista que veía el socialismo como un mundo de aburrimiento menos injusto que el capitalismo de libre iniciativa y máxima innovación es hoy más realista que el Fukuyama que parece temer el aburrimiento de un mundo industrializado de hegemonía neoliberal"263.

El hecho de que alguien se haya apresurado a decir "Nosotros ganamos", significa que 'se comienza a olvidar algo que es fundamental: que si no ganamos todos nadie va a ganar realmente y que, por otra parte, hoy nadie puede engañar a nadie seriamente y por mucho tiempo, como explica muy bien Gorvachov en la perestroika. Además eso sería volver a concebir la historia como historia de los "dominadores". Y. entonces sí que estamos en el fin de la historia en su peor sentido, su disolución. Esa es la razón por la cual: "La disolución de la historia, en los varios sentidos que pueden atribuirse a esta expresión es probablemente, por lo demás, el carácter que con mayor claridad distingue a la historia contemporánea de la historia ¡moderna!"264. La historia como éxito y simple progreso ya no existe sin más. Y la revolución verdadera sólo será en el futuro la que realmente reconozca a los oprimidos de la tierra: "En consecuencia, ésta (la revolución) pretende llevar a término una especie de redención que haga justicia, es decir, que vuelva a dar la palabra a todo aquello que ha sido excluido y olvidado en la historia lineal de los vencedores"265. Sólo así es posible apropiarse de nuevo el sentido de la historia y resucitar a la falta actual de sentido. Pero entonces todo cambia, la historia ya no es la historia del mundo triunfante sino la historia del hombre herido, caído en el borde del camino, apaleado por los ladrones y que necesita del buen samaritano, de todos nosotros: "El verdadero trans-

262 WALTER, E., How Capitalism can be king of world's moral mountain. National Catholic Reporter, 1 (9.1989) 28: "If the most advantaged people were the most principled and socially responsible people, the United States would 'sit unchallenged on top of the moral world"”.

263. Paramio, L., El fin de la prehistoria. El País (21.12.1989) 16

264 VATtimo, G., El fin de la modernidad, 17

265 Vatтimo, G., A. Rovatti, El pensamiento débil, 23 
cendental, lo que hace posible cualquier experiencia del mundo es la caducidad; el ser no es, sino que sucede, quizás también en el sentido de que cae junto a, de que acompaña -como caducidad- a cualquiera de nuestras representaciones"266. Esto hace que no solamente nos importen en la marcha de nuestra historia, los fuertes y los triunfantes sino también los débiles y los marginados: "La piedad por estos despojos representa el único verdadero motivo de la revolución, más que cualquier proyecto presuntamente legitimado en nombre del derecho natural o del curso necesario de la historia"267. Solamente así la historia y su final será perfecta y verdadera y el fin de la prehistoria.

Por último no es posible olvidar que aún somos en gran manera prisioneros de la historia ${ }^{268}$. Este es un análisis fundamental que ni nosotros ni Fukuyama podemos dejar de lado. La situación actual, aún reconociendo un gran salto hacia adelante y un cambio de paradigma realmente importante no es tan inocente ni bondadosa como Fukuyama se imagina. El mundo no es tan benevolente ni tan sencillo como nuestro autor parece creer. A pesar de la postmodernidad, el mundo trata de hacernos suyos, objeto de sus negocios e incluirnos en la "industria de las conciencias", con la liquidación técnica de los valores, precisamente mediante cao técnico. La sociedad y la técnica actual no permiten referirnos a valores ni tenerlos realmente en cuenta, eso iría contra la técnica, al menos, contra la de los vencedores. Entonces es necesario dejar de entender la historia y el progreso como "nostalgia del Imperio". Y la política y la moral deben corregir los aspectos salvajes del proceso económico social. En efecto, la economía tiene leyes salvajes que no puede admitir ni la política ni la moral: "Yo puedo admitir que la economía se gobierne por estos principios, pero la política tiene que corregir los aspectos salvajes de esta aplicación. La moral tiene que ser una corrección de la voluntad de vivir que se afirma en las instancias técnicas" 269.

Esta labor es indeclinable para que no lleguemos a los excesos consecuentes que por desgracia nos son bien conocidos: "El fascismo y el estalinis-

266. Ib., 34

267. Ib., 41. Como genialmente escribió L. Cilleruelo: "El increíble e indudable éxito del marxismo, no se debe a su filosofía ni a su ciencia, ni a su mística o seudereligión, sino a los principios que tomó del cristianismo, como expresamente se realza en la parábola del Buen Samaritano: en un tiempo en que el proletariado cayó en manos de los ladrones, Marx hizo lo que no hicieron el sacerdote y el levita". CILLERUELO, L., Angeles sin paraíso. Estudio Agustiniano, 25 (1990) 242

268. Foucault, M., Prisioneros de la historia. El País. Temas de nuestra época. (8.6.1989) 4

269. Vatтimo, G., Filósofo de la secularización. Revista de Occidente 104 (1990) 130 
mo han utilizado y extendido mecanismos ya presentes en la mayor parte de otras sociedades. No solamente esto, sino que, no obstante su locura interna, han utilizado, en una gran medida, las ideas y los procedimientos de nuestra racionalidad política" 270 .

Debemos estar vigilantes y no esperar hasta que lleguen los excesos de demencia del poder político para reconocer la evidencia. Es necesario crear una resistencia adecuada para impedir la gran niveladora de la racionalidad, darnos cuenta del abuso del poder en su propio ejercicio. No se trata sólo de criticar la Ilustración hay que ver los mecanismos actuales que nos hacen aún prisioneros de la historia: "Incluso si la Ilustración ha constituido una fase muy importante de nuestra historia y el desarrollo de la tecnología política, creo que es preciso remontarse a procesos muchos más alejados si se quiere comprender por qué mecanismos nos hemos encontrado de nuevo prisioneros de nuestra propia historia"271. En las luchas feministas, en el conflicto generacional, en la antipsiquiatría y las protestas contra la burocracia se trata de afirmar el derecho a la diferencia y al propio ser y oponerse al poder que quiere aislarnos, separarnos de los otros y del sentido solidario para replegar al individuo sobre sí mismo y "atarlo a su identidad" como el poder lo ha acordado. Estas luchas se oponen al gobierno y a la administración: "Oponen una resistencia a los efectos del poder que estén ligados al saber, a la competencia y a la cualificación. Luchan contra los privilegios del saber. Pero se oponen también al misterio, a la deformación, a todo lo que puede haber de mistificador en las representaciones que se imponen a las gentes"272. Es una lucha contra el saber perdido en el poder. Se trata de nosotros mismos y de nuestra autenticidad: "En fin, todas las luchas actuales irán en torno a la misma cuestión: ¿quiénes somos nosotros? Aquellas son el rechazo de estas abstracciones, un rechazo de la violencia ejercida por el Estado económico e ideológico, que ignora quiénes somos individualmente, y también un rechazo de la inquisición científica o administrativa que determina nuestra identidad"273. Este sistema clasifica administrativamente a las personas, les impone una identidad y una ley de verdad que tienen que aceptar por las buenas o por las malas. Así el hombre queda sujeto al poder reinante con una alegría y una espontaneidad adolescente e ingenua: "Hay dos sentidos en la palabra sujeto: sujeto sometido a otro por el control y la

270. Foucault, M., Prisioneros de la historia, 4

271. Ib., 4

272. Ib., 4

273. Ib., 4

274. Ib., 5

275. Ib., 5 
dependencia, y sujeto atado a su propia identidad por la conciencia o el conocimiento de sí. En ambos casos esta palabra sugiere una forma de poder que subyuga y sujeta"274.

Hoy más que nunca debemos ser nosotros mismos para liberarnos de la industria del poder y de las conciencias. No basta liberarse del dominio y de la explotación social, religiosa o económica: "Hoy es la lucha contra las formas de sujección -contra la sumisión de la subjetividad- la que prevalece cada vez más, aun cuando las luchas contra la dominación y la explotación no han desaparecido, bien al contrario"275. Pero los mecanismos de sumisión no son meramente la terminal de los problemas socio-económicos. Se trata del "poder pastoral" del estado que no sólo olvida a los individuos si no que establece sobre ellos un poder global y totalizador, de cuerpo y alma, que trata de constituirse en mesías y salvador. Como poder soberano esta forma de poder "es coextensiva a la vida y a su prolongación; está ligada a una producción de la verdad -la verdad del individuo mismo"276. Este poder pastoral antiguamente sólo propio de la iglesia, tenía sus propias características de disponibilidad y servicio al hombre. "El poder pastoral no es simplemente una forma de poder que ordena. Debe estar también dispuesto a sacrificarse por la vida y la salvación del rebaño. En esto se distingue pues del poder soberano que exige un sacrificio por parte de sus sujetos para salvar el trono"277. Pero el Estado no sabe nada del espíritu del buen pastor y se posesiona del hombre de tal modo que profana los secretos íntimos y los repliegues últimos de su vida y su alma. Así hace a los individuos a su imagen y semejanza y los vampiriza absolutamente bajo el señuelo de la libertad y la integración social. "En un sentido, se puede ver en el Estado una matriz de la individualización o de una nueva forma de poder pastoral"278. Como el mal pastor que no le importan demasiado sus ovejas sino su carne y su abrigo, el Estado utiliza todos los medios a su alcance para difundir su poder: la familia, la educación, la administración, la sanidad, etc. Es hoy pues más urgente que nunca saber lo que somos y lo que debemos ser. Rechazar el falso individuo que somos, dar de lado al individualismo y al universalismo vacío del poder moderno. "Podrá decirse, para concluir, que el problema a la vez político, ético, social y filosófico que se nos plantea hoy, no es tratar de liberar al individuo del Estado y de sus instituciones, sino librarnos nosotros del Estado y del tipo de individualización que está ligado a él. Nos es preciso

276. Ib., 5

277. Foucault, M., Por qué hay que estudiar el poder: la cuestión del sujeto. Liberación $6(30.12 .1984) 7$

278. Foucault, M., Prisioneros de la historia, 5 
promover nuevas formas de subjetividad rechazando el tipo de individualidad que se nos ha impuesto durante varios siglos"279.

Todo esto lo sabe perfectamente Fukuyama sin que haya entrado verdaderamente en el fondo del asunto. Por tanto, es una ingente tarea la que nos espera, como el mismo autor reconoce, y llevará mucho tiempo. La historia, nuestra hisțoria, no va a ser un camino de rosas. Pero es igualmente cierto que la postmodernidad está ahí; toda esta denuncia forma parte de su cara negativa, como la bancarrota de la realidad, la agonía de la razón cínica o las éticas políticas postmodernas. Esta ha sido la tarea de zapa y de preparación del terreno que espero no haya sido meramente negativa. Se anuncia ya un nuevo horizonte. Ahora solamente se trataba de: "Libertar al mundo de los símbolos de sujeción a la "realidad" asentada y vigente desde antes que él, que lo domina y mide a través de criterios como el de la objetividad, -en esta liberación consiste finalmente la afirmación lingüística del ser"280. Queda pues la tarea compleja de la aplicación postmoderna en metafísica, en antropología y sociología, en pedagogía y en teología. Pero eso será otro día...

D. NATAL 